\title{
UK house prices and three decades of decline in the risk-free real interest rate
}

\author{
David Miles ${ }^{1}$ and Victoria Monro ${ }^{2}$ \\ ${ }^{1}$ Imperial College London \\ ${ }^{2}$ Bank of England
}

December 16, 2020

\begin{abstract}
House prices have risen substantially faster than the prices of consumer goods in most G7 countries over the past few decades. This raises major policy issues: such rises affect the distribution of wealth within and between generations, the mobility of labour and financial stability. This paper explores why such rises have happened, and what the policy implications are. The price rises have been greatest in the UK, where real house prices have risen more than three and a half times since the 1970s, substantially outpacing real income growth. Meanwhile, rental yields have been trending downwards - particularly since the mid-90s. This paper reconciles these observations by analysing the contribution of a number of drivers of house prices. It shows that the rise in house prices relative to incomes between 1985 and 2018 in the UK can be more than accounted for by the substantial decline in real risk-free interest rates over the period. This is slightly offset by net increases in home-ownership costs from higher rates of tax. Changes in the risk-free real rate are likely to have been a major driver of changes in house prices. We analyse why they have driven house prices up faster in the UK than in other advanced economies. Our model predicts that a 1\% sustained increase in index-linked gilt yields from current rates could ultimately result in a fall in real house prices of around $20 \%$.
\end{abstract}




\section{Introduction}

House prices in most developed economies have risen greatly over the past few decades. This has significant implications for the distribution of wealth - both within, and particularly between, generations. It may be affecting labour mobility and the regional patterns of development within countries - often in unhelpful ways. As households take on more mortgage debt to buy more expensive homes, strains on affordability rise, generating financial stability risks. Understanding why this has happened - why the prices of houses are so much higher relative to the prices of other goods - is crucial to thinking about the appropriate policy responses. Several factors may have contributed to substantial and sustained price rises: housing supply elasticities are clearly relevant; movements in the cost and availability of mortgages matter; waves of optimism and pessimism may have inflated and deflated bubbles so that some big movements in prices may have been unrelated to fundamentals.

Different underlying drivers of house prices would imply very different policy responses. If a low supply elasticity, stemming from overly restrictive planning or limited capacity in the construction sector, is the key factor, that suggests a different set of policies than if the main driver of higher house prices is low interest rates. And if low interest rates is the main factor behind the rise in prices in many countries it matters greatly whether that is largely a consequence of monetary policy decisions or is instead a reflection of movements in longer term real interest rates that are not closely related to the policy choices made by central banks (which concern short-term nominal interest rates).

This paper assesses the relative role of different factors in driving house prices in the G7 country where real house values over the past several decades have risen faster than anywhere else - the UK. We draw out the policy conclusions of this analysis.

Figure 1 shows growth in average real house prices in each of the G7 economies from 1980 to 2018. The series for average nominal house prices for each country is deflated by the relevant consumer price index and the resulting real index is set to 100 in 1980 11 Over this period, Japan Italy and Germany have experienced house price rises roughly in line with other prices. In other G7 countries house prices over the past forty years have risen faster than consumer prices. In the UK, average real house prices (adjusted for the consumer prices measure of inflation) are now significantly more than three times as high as in 1980. So, while the majority of these countries 


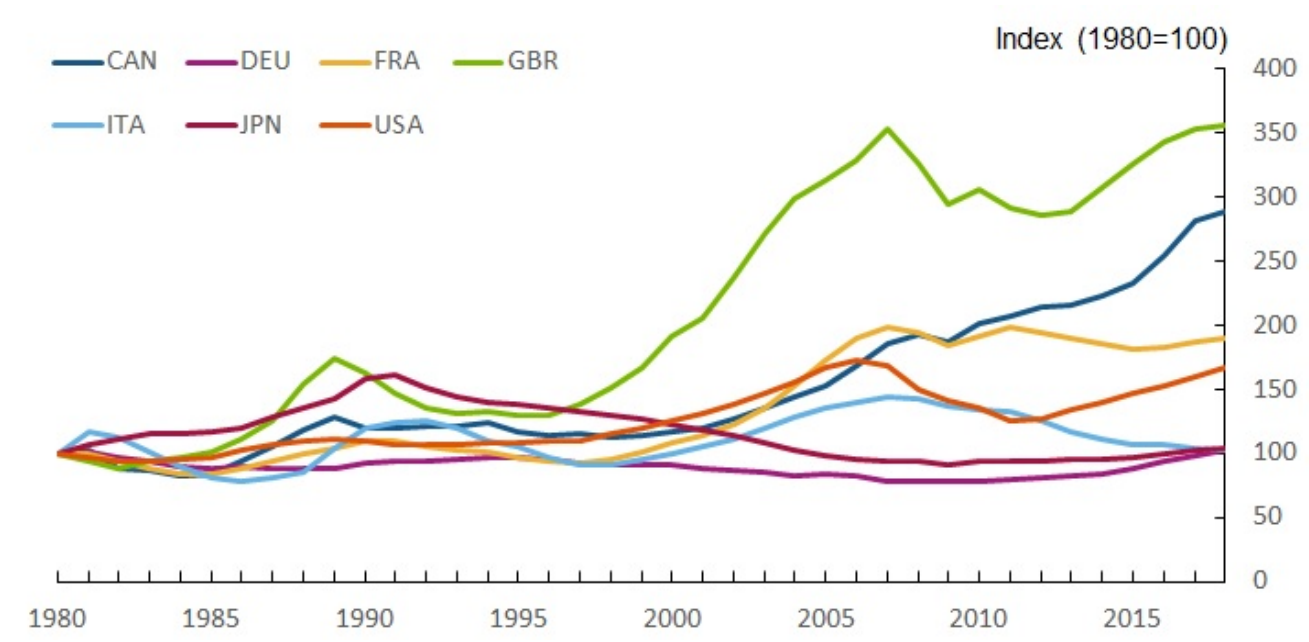

Figure 1: Real house price growth in G7 countries (1980-2018) a

\footnotetext{
${ }^{a}$ OECD housing prices database - real house prices, $1980=100$
}

experienced significant real house price growth over the period, the UK saw the fastest rise of all.

Figure 2 shows UK house prices over a longer period, going back 50 years, with a breakdown for the four home countries. In real terms (that is, relative to consumer goods prices as measured by the Retail Price Index, which over this period has been the main measure of inflation) UK house prices were more than three and a half times greater at the end of 2018 than at the end of 1968. In terms of the official Consumer Price Index, we estimate a much larger rise, to around five times the 1968 levels. Of course this is an aggregate price index for a good - housing - that is not at all homogenous. Every house is unique, if only by location but usually by a long list of other characteristics as well. In this paper we will be focusing on overall trends in values of housing, but will also consider why regional differences have been significant. While there has been substantial regional variation in the rate of price increases, prices over the past several decades have increased enormously across all of the home nations of the UK.

To some extent it is perhaps not surprising that house prices have risen faster than the price of consumer goods in general. Technical progress has brought down the quality-adjusted prices of some goods - computers, phones, cars - far more than houses where building methods have not changed as much. But the scale of the rise in the price of homes relative to goods and services in general is very large. House prices in the UK have also risen substantially faster than incomes. By 2018, average house prices were not far off twice as high relative to a measure of average

\footnotetext{
${ }^{1}$ This data comes from the OECD's housing prices database, available here: https://data.oecd.org/price/ housing-prices.htm. The inflation measure used is consumer prices for each country.
} 


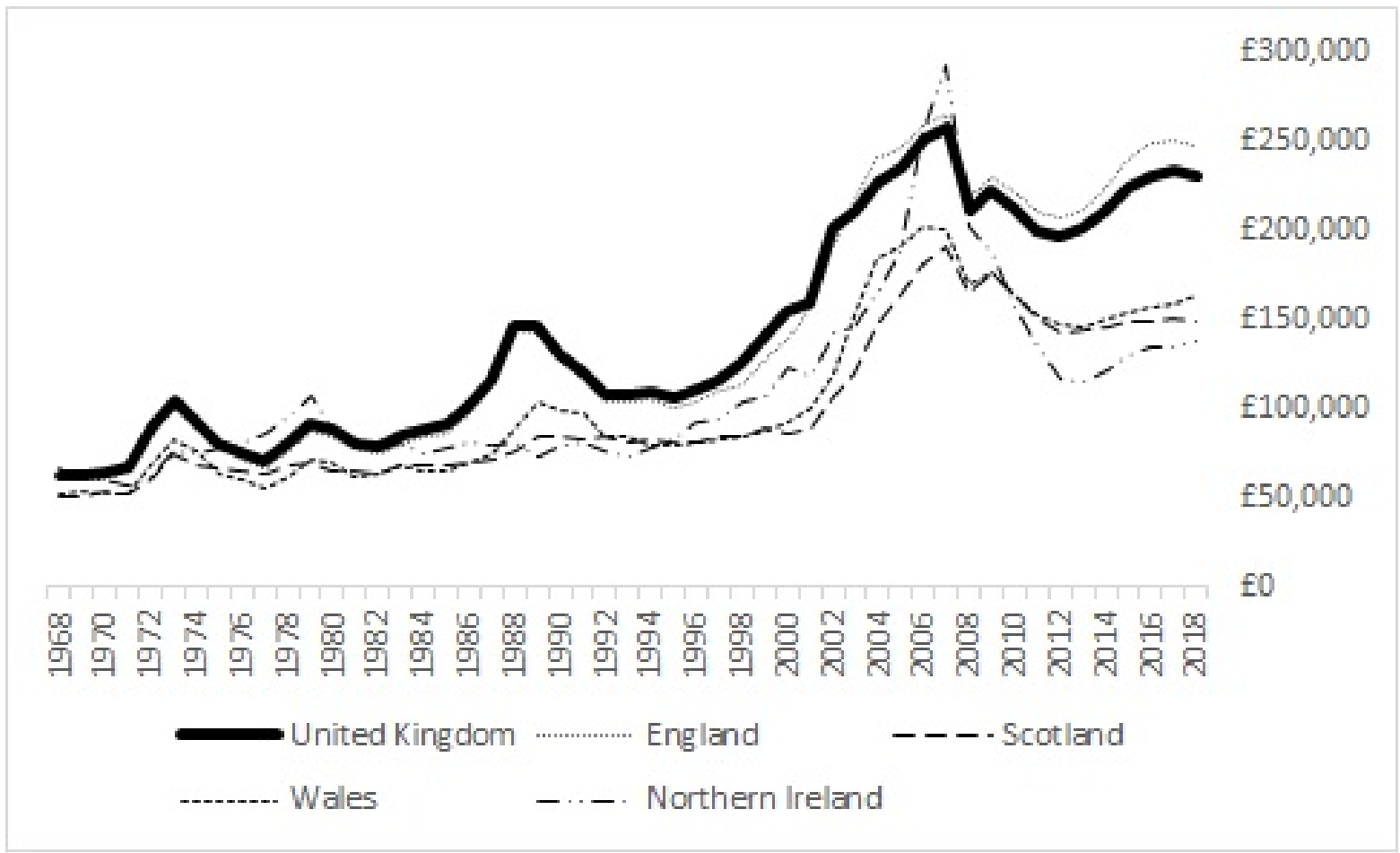

Figure 2: Average real house prices (1968-2018 a

\footnotetext{
${ }^{a}$ ONS UK House Price Index, deflated for RPI and in 2018 pounds. Data available at the HM Land Registry website.
}

household disposable income as they were almost 40 years ago - this is an income measure that already takes into account the rise in the average number of earners per household (Figure 3). Relative to average earnings per worker, house prices have roughly doubled between the early 1980s and 2018:2

This paper sets out an explanation for this dramatic rise in the price of buying a house. It focuses on the national picture for the UK, and less on regional differences. It models the long-run trends, rather than short- term fluctuations, assessing whether the rise in house values across the last 35 years can be explained in terms of economic fundamentals, or whether it has been on such a scale as to suggest inflated values (loosely speaking, what might be called a 'bubble'). One reason to take the view that values today may be far in excess of what is justifiable in terms of

\footnotetext{
${ }^{2}$ This may understate the increase in the ratio. An ONS series available from 2002-2018, which compares the residence-based median gross earnings of full-time workers to the median house prices (for England and Wales only) produces a house prices to earnings ratio very similar to our best estimate for 2002, but the ratio increases significantly, reaching almost 8 times gross full-time earnings in 2018. See the ONS dataset 'House price to residence-based earnings ratio', available at https://www.ons.gov.uk/peoplepopulationandcommunity/ housing/datasets/ratioofhousepricetoresidencebasedearningslowerquartileandmedian.
} 


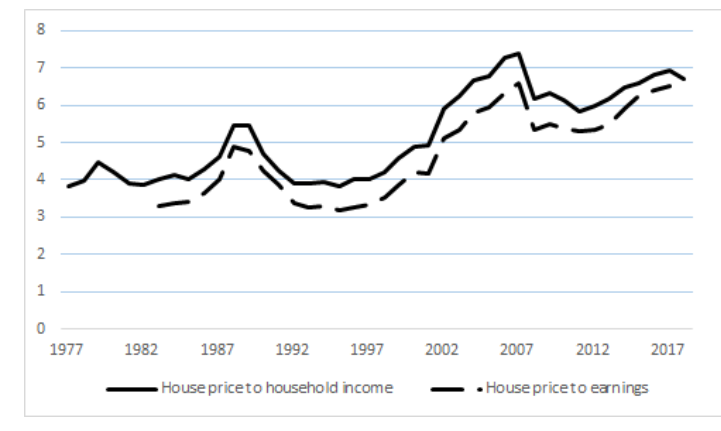

Figure 3: Average UK house price to a measure of household income, and individual earning $\S^{a}$

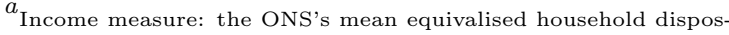
able income, taken from the data release "The effects of taxes and benefits on household income, disposable income estimate". Earnings measure: ONS series for full-time working adults in Great Britain, weekly gross pay, taken from ONS ad hoc data release reference 006301 (note the slightly different coverage: UK house prices but GB earnings data). House prices: UK House Price Index.
}

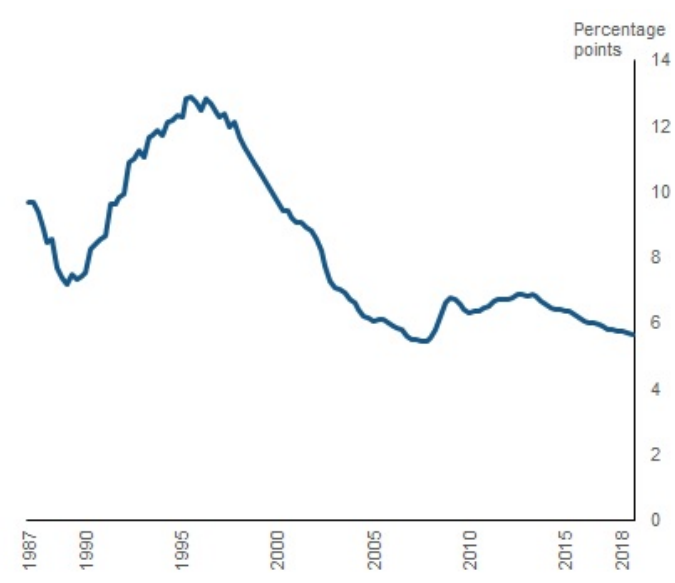

Figure 4: The rental yield (1987-2018) ${ }^{a}$

\footnotetext{
${ }^{a}$ Data based on the Bank of England Financial Policy Committee's core indicator on prices to rents, rebased to Zoopla residential property prices. This rental series is constructed using data from lettings agents.
}

fundamental factors (e.g. incomes, demographics, interest rates) is that in the UK rents have not risen in line with house prices. Figure 4 shows a measure of rental yields (average rents relative to average house prices), which has fallen substantially over the past thirty years. But we find that the decline in rental yields is not a sign that houses are overpriced.

We use a model of the housing market that puts changes in the demand for housing, in part driven by changes in the effective cost of home ownership, at its core. Shifts in interest rates are an important element of the effective cost of home ownership and such shifts have been very large. We use this model to show that the sharp rise in house values and substantial decline in rental yields can be reconciled with a fundamental equilibrium that links the two together, and therefore we reject the hypothesis that there is a UK house price bubble.

The model makes three factors central to understanding the evolution of house prices: shifts in the user costs of housing, changes in income, and supply and demand elasticities. Poterba (1984) contains the original derivation of the model; Miles (1994) provides an extended exposition and applications. Himmelberg et al (2005) assess whether US house prices are out of line with fundamentals with a model that puts the user cost at its centre; as in their paper, the user cost plays a key part in our analysis. It is distinct from the price of buying a house; but the price of a house is likely to be very sensitive to the user cost. The user cost of housing depends upon tax factors, costs of depreciation and repairs, anticipated house price inflation, and interest rates: our 
contribution is to assess the relative significance of all these factors for the huge increase in real UK house prices over the past 35 years. We isolate the impact of changes in real interest rates and find that the key factor in reconciling the divergent trends between house prices, incomes and consumer prices is that there has been a substantial decline in real interest rates, spanning decades, which was consistently not expected I $^{3}$ Even an anticipated decline in interest rates would have boosted house prices greatly, but there is strong evidence that the decline in real interest rates was largely unanticipated and that this made the impact on house prices even greater.

Our analysis factors in plausible estimates of supply and demand elasticities for housing important factors behind the transmission channel from changes in real interest rates to changes in real house prices. But a low supply elasticity not in itself account for more than a part of the rise in prices. Were the supply elasticity for new house building in the UK much higher, the rise in house prices generated by very low interest rates would likely still have been significant. We find that the majority of the rise in UK house prices observed over the period would still have occurred had the elasticity of supply of the stock of housing been twice as large as it actually is over the entire period.

When it comes to valuing houses, relevant factors are the rates of return that could be earned on wealth held in forms other than housing and also, for people with mortgages, the cost of borrowing. We assume that both those factors reflect the sum of a safe return and risk premia. Our measure of the safe return is the real yield on a inflation-proof bond issued by a government that is very unlikely to default. The results suggest that the nearly 6 percentage point decrease in the yield on inflation-proof UK government debt between 1985 and 2018 may have caused a doubling of average UK real house prices across the period. Nearly all of the rise in average house prices relative to incomes can be seen as a result of a sustained, dramatic, and consistently unexpected, decline in real interest rates as measured by the yield on medium-term UK index-linked gilts.

There is evidence that the important role we think a decline in real interest rates has played in driving house prices higher has affected other long-lived assets. Kuvshinov and Zimmermann

\footnotetext{
${ }^{3}$ Nickell was one of the first to stress the quantitative significance of this factor for UK house prices back in 2005 in his Keynes Lecture at the British Academy: "Practical Issues in UK Monetary Policy 2000-2005".

${ }^{4}$ The National Audit Office's report on housing in England (2017), for example, notes that "Housebuilding between 2011 and 2015 did not keep pace with demographic projections" - reflecting reduced construction, population growth, and smaller household sizes. This is consistent with the findings of the 2004 'Review of Housing Supply' final report, commissioned by the Government (Barker, 2004).
} 
(2020) find that a decline in discount rates from around 1980 has driven up the value of equities globally so that prices since 1870 have a hockey stick shape from around the period when we find real interest rates began their downwards descent.

Our model implies that changes in interest rates have a much more powerful effect on house prices when interest rates are low: at the end of 2019, the yield on 10 year index-linked bonds was $-2.4 \%$. We find that an unexpected and persistent increase in the medium-term real interest rate of 1 percentage point from that level could ultimately generate a fall in real house prices (potentially over a period of some years) of approximately $20 \%$.

The decline in the real risk-free interest rate has been an international phenomenon, and yet as shown in Figure 1, house prices have followed different paths in different countries. But across the G7 countries there have been differences in the path of real interest rates, as well as in incomes, and supply and demand elasticities. We show that the differences across countries in these factors is large enough to have generated very substantial differences in house price growth.

We stress that the decline over 35 years in real interest rates is not a reflection of loose monetary policy. Central banks control the level of short-term nominal interest rates - not the level of medium and longer term real interest rates. As noted, the sustained decline in real yields is not unique to the UK; it is also one which long pre-dates quantitative easing operations.

From a policymaker's perspective, these results have several implications for housing affordability, labour mobility, inter-generational welfare and financial stability. Whilst increasing the responsiveness of supply to price changes may have some effect, our results from a hypothetical doubling of the supply elasticity mean it is unlikely that we can simply build more houses to take real house prices back to the levels of a few decades ago. Instead, we suggest that a change in UK taxes on home ownership may ameliorate some of the effect of low interest rates, as well as being justified on the grounds of efficiency.

Our results are also relevant to financial stability issues. If the trend of falling rates continues, the household sector could become increasingly leveraged. Highly indebted households can worsen an economic downturn by cutting back consumption to service their debt, so the risks that the financial sector amplifies a downturn are likely to be greater. Whilst we do not think it is plausible that real interest rates are going to revert to much higher levels in the near-term, such a reversion to non-negative levels could result in significant real house price falls, adversely impacting households and the banking sector that is significantly exposed to house price falls through its mortgage book. 


\section{Related literature}

There is a substantial literature that addresses the issue of why house prices have risen so much in recent decades, some of it focused specifically on the UK (see, for example, Muellbauer (2018), Duca et al (2016)). Much of that literature focuses on supply constraints and planning restrictions - particularly when it seeks to explain differences in price changes within countries (see, for example, Glaeser et al (2005) and Vermeulen and Hilber (2014)). When the focus is on the overall level of national prices over time - as in this paper - the impact of changes in incomes and in the level of interest rates, and its interaction with supply elasticities, becomes central (see for example Geng (2018) for recent cross-country estimates of drivers of house prices). The impact of shifts in the cost of credit (and its availability) has been the subject of much work. Glaeser et al (2012) argue that shifts in interest rates have not been a particularly powerful factor, but that is because the shifts they look at seem not have been persistent and mean reversion dampened their impact. In contrast, we focus on the effect of changes in longer-term, real rates where the evidence strongly suggests that such changes have been largely unexpected but very highly persistent.

Garriga et al (2019) look at the impact of interest rates and the availability of credit finding they played a major role in house price changes in the US. Like us they consider why house prices and rents seem disconnected in recent years. The user cost approach used in our paper is key to explaining this disconnect. Himmelberg et al (2005) argue that the user cost approach (linking rents to the user cost of housing) is essential for uncovering whether house prices are reflective of fundamentals or bubbles. In much of the literature a user cost approach to the estimation of house values is now used - sometimes alongside alternative valuations based on the borrowing capacity of households. (For a recent application of house price valuation based upon a user cost approach, and an alternative borrowing capacity approach, see Andrle and Plašil (2019).)

Knoll et al (2017) describes how house prices have moved over very long periods across developed economies; the facts uncovered in that paper have motivated the development of models looking at fundamental drivers of prices over many decades rather than over business cycles. One example of this is Miles and Sefton (2020) whose model makes the user cost central to the demand for housing and in particular focuses on transport developments in their analysis of supply.

One of our contributions is to show that changes in the most fundamental driver of the opportunity cost of resources devoted to housing - that is the medium-term, safe, real interest rate

- have been dramatic, largely unanticipated, persistent and (plausibly) exogenous to the housing 
market changes in the UK. This has allowed us to generate estimates of their contribution to price rises across the past several decades using the user cost approach that is standard in much of the housing literature.

The remainder of the paper is organised as follows: Section II sets out our modelling framework, derives the equilibrium conditions, and offers values for the various components of the model; Section III explores the role of price and income elasticities of demand and the price elasticity of supply in determining the effect of the real risk-free rate on house prices; Section IV uses the model to account for long-run trends in UK house prices; Section $\mathbf{V}$ concludes and draws out policy implications.

\section{Modelling equilibrium in housing}

\section{Setting up the model}

Our analysis draws upon the idea that households aim to maximise their utility from consuming goods and housing services over a lifetime, subject to a budget constraint. We assume that some households at some points in their life are able to borrow enough (or else have accumulated sufficient wealth) to buy a house and so have a choice between renting housing services or buying a house and enjoying the services it brings as an owner-occupier. They are the marginal buyers: as in all markets, it is marginal buyers and sellers that determine prices. If there are households who face that choice, and some of whom are indifferent between owning and renting at the margin, then the effective cost of housing services from owning a property and from renting will be equal. This ties down a relation between the price of a house and rents - a relation that depends on interest rates, the costs of home ownership in the form of depreciation and taxes, and anticipated capital gains. In the appendix we derive this condition from the household optimisation problem. Essentially the condition is that the cost of housing services to an owner-occupier (the "user cost of housing') should equal the rent due to acquire equivalent housing services.

This user cost of housing $\left(U C H_{t}\right)$ is a measure of the economic cost of owning a house for a period - it is the effective price of housing services as distinct from the price of buying the durable asset 'a house'. In equilibrium, it should be equal to the value that households place upon the services derived from using a house. That, in turn, should equal the cost of renting if we have equilibrium in both the markets for home ownership and for renting, and there are some people 
indifferent between the two forms of housing tenure. Another way to interpret this equation is that it generates equality between (i) the return from buying a house and renting it out and (ii) the return on other potential investments. That is an equilibrium condition for investors who consider the returns from being a landlord relative to those on alternative assets.

In the appendix, we show that the user cost for period $t$ is defined by:

$$
U C H_{t}=P_{t}^{H} \cdot\left[b \cdot R M_{t}+(1-b) \cdot R A_{t}+\delta_{t}+C T_{t}+P O_{t}-E\left[\rho_{t}\right]\right]
$$

The first term in square brackets, $b \cdot R M_{t}$, is the proportion of the house bought with mortgage debt, $b$, multiplied by the mortgage rate, $R M_{t}$. The second term is the proportion of the house funded from the home owner's wealth, $(1-b)$, multiplied by the return that such wealth could earn if invested in assets with similar risks to that of housing, which we denote $R A_{t}$. The sum of these terms is the weighted average cost of funding. We will assume that the cost of each source of funding is the sum of a safe real interest rate, $R_{t}$, and a risk premium. Mortgage lenders charge a premium over a safe real interest rate they could receive (for example by investing in government bonds rather than lending on mortgages) - denoted $R P M$. So, $R M=R+R P M$. Returns on assets with the same risks as housing can be written as $R A=R+R P H$, where $R P H$ is the risk premium over a safe rate on assets with similar risks to housing. We define an overall risk premium, $R P_{t}$, as $b \cdot R P M_{t}+(1-b) \cdot R P H_{t}$, which is a weighted average of the premium on mortgage interest rates over a safe rate and the premium over the safe rate of the return needed on assets with similar risk characteristics to housing. If we use these assumptions we can re-write Equation 1 as:

$$
U C H_{t}=P_{t}^{H} \cdot\left[R_{t}+\delta_{t}+C T_{t}+P O_{t}-E\left[\rho_{t}\right]+R P_{t}\right]
$$

We measure the house price in real terms so the user cost is a real cost. The term in square brackets are costs per period as a percentage of the house price. The house price, $\left(P_{t}^{H}\right)$, is measured as the nominal house price relative to an index of the prices of goods and services. The per-period costs of home ownership relative to the house price are:

- the risk-free return $\left(R_{t}\right)$ that could be earned on an investment in an asset generating known real returns. We will proxy this by the yield on an inflation-indexed goverment bond; in the UK this is the yield on an index-linked gilt; 
- a comprehensive measure of the costs incurred to maintain the property, including depreciation, maintenance and insurance $\left(\delta_{t}\right)$;

- taxes levied on users of housing - both owner-occupiers and renters - i.e. council tax $\left(C T_{t}\right)$;

- net taxes on owners of housing $\left(P O_{t}\right)$ - e.g. stamp duty on property purchase net of any mortgage interest relief;

- decreased by the expectation of future real capital gains $-E\left(\rho_{t}\right)$ - this is the expected rise in real house prices;

- plus the risk premium for housing $\left(R P_{t}\right)$. For an owner with no mortgage, the risk premium reflects the extra expected return they need on a house over and above the safe rate to reflect its risk as an asset. The premium over the safe rate for someone who finances the house partly with debt reflects two underlying premia: (i) the risk premium paid on the part of the house financed by their own wealth, and which is the same as would exist for a owner with no debt; and (ii) the spread over the safe real rate to reflect the risk of mortgage debt.

We do not directly adjust returns (either $R_{t}$ or $R P_{t}$ or the capital gain, $\rho_{t}$ ) for tax for two reasons: (a) mortgage debt is no longer tax deductible in the UK while the opportunities to save in forms where asset income is free of tax (via pensions or ISAs) is substantial, and (b) in the UK, capital gains is untaxed for owner occupied housing, and partially offset by costs incurred by landlords in the rental market. But we do allow for mortgage interest tax relief, when it was available for home owners, in the term $\mathrm{PO}_{t}$.

In equilibrium, the marginal homeowner should be indifferent between home ownership and renting. This equilibrium condition is given in Equation 3, which says the comprehensive, perperiod cost of living in a property you own should be equal to the cost of living in rented accommodation (the real rent, $R R_{t}$ ) after accounting for any tax that is liable for a renter (e.g. council tax: $\left.P_{t}^{H} \cdot C T_{t}\right)$.

$$
U C H_{t}=R R_{t}+P_{t}^{H} \cdot C T_{t}
$$

There may be many people for whom renting has an added benefit of flexibility over homeownership, and others for whom owning a property has intrinsic value (such as, for security) over 
renting the same property. We require that at the margin there are some who will be indifferent and this is consistent with such preferences for some non-marginal households.

Equations 2 and 3 imply:

$$
P_{t}^{H}=\frac{R R_{t}}{R_{t}+\delta_{t}+P O_{t}-E\left[\rho_{t}\right]+R P_{t}}
$$

Equation 4 is an implication of rents being equal to the user cost of housing. Again, this is a marginal condition: it does not require that every person can borrow enough to buy a house. It does require that there are people that have choices between either renting and investing their money into other assets, or buying a property. This is important because it means that the prevalence of 'reluctant renters' - renters who would like to purchase property but cannot access sufficient credit to do so - does not undermine our central assumption. We do not need to make any further assumptions about the availability of credit, provided that there are some investors that are not constrained in their ability to borrow against housing collateral at the margin.

The assumption that there is a significant group of potential buyers who are not credit constrained, and for whom the equilibrium conditions (3) and (4) - as well as equation (5) below hold, is a strong one. These marginal buyers are those who would switch to owning a little less housing (or a little more) if the conditions no longer held. But, as a group, they need to be large enough so that such switches move rents and home prices enough to ensure the condition holds once again following some temporary deviation form it. For the period we consider (1985 to 2019) it is plausible that this unconstrained group was indeed large. The major easing in credit conditions in the UK mortgage market had largely happened by the start of this period; the building societies domination of the UK market, and the cartel they ran on pricing that generated quantity rationing, had ended by 1985 when UK banks began to dominate the market. Regulations on the funding of building societies was also eased in the mid 1980s 5 More recently, the private buyto-let market has become substantial and so private investors with access to credit can increase (and decrease) their holdings of rental property if house prices and rents appear to make the likely returns exceed (or fall short) of the risk adjusted required returns.

This is not to say that credit conditions do not have an effect on house prices however - we indicate one channel for credit availability to affect house prices in Section IV.

\footnotetext{
${ }^{5}$ See Bank of England Qurterly Bulletin, 1990 Q4: "The Development of the Building Societies Sector in the 1980s". Available here: https://www.bankofengland.co.uk/quarterly-bulletin/1990/q4/ the-development-of-the-building-societies-sector-in-the-1980s
} 
The rental yield is $R R_{t}$ relative to $P_{t}^{H}$, so Equation 4 implies:

$$
\text { Rental yield }=\frac{R R_{t}}{P_{t}^{H}}=R_{t}+\delta_{t}+P O_{t}-E\left[\rho_{t}\right]+R P_{t}
$$

We use Equation 4 to explore the drivers of UK real house prices over the last 35 years. We use Equation 5 to assess whether the trends in the rental yield over time move in a way consistent with the model. To do this we face a series of measurement issues, the first of which is how to measure the risk-free rate and expected capital gains.

\section{Measuring the risk-free rate and expected capital gains}

Index-linked gilt yields provide a natural empirical counterpart to the concept of 'the UK safe real rate $^{6}$, but which horizon is the most appropriate is less clear. Owner-occupiers typically own a single house and live in it for many years before moving - that might suggest a relatively longterm yield with a maturity of 10 years or even more. Renters may have a time horizon of a year or so - though landlords may take a longer term view of the required real return and see the risk-adjusted medium-term real yield as what they aim to match through rental income and any capital gain. In practice, however, it makes rather little difference whether we use short dated (1-5 year) index-linked yields or medium dated yields (10 years) or long-term yields (20 years) the trend in all is common (Figure 5).

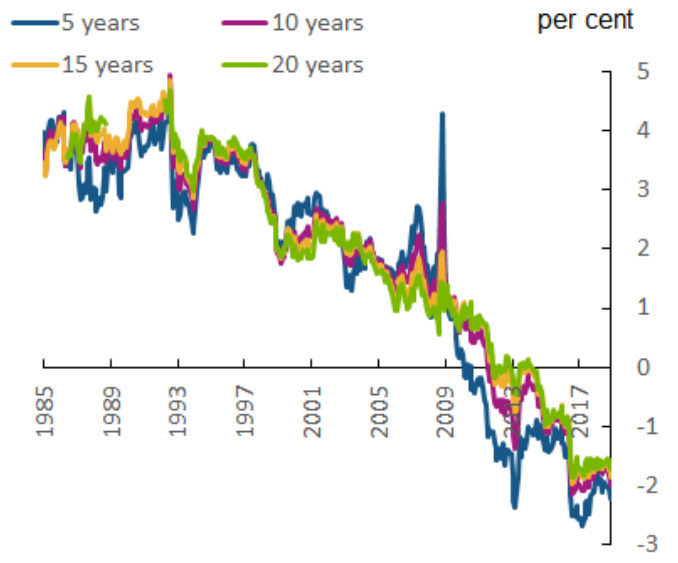

Figure 5: Index-linked gilt yields, by term $(1985-2018)^{a}$

\footnotetext{
$a_{\text {The data on yields for index-linked gilts is published by the Bank }}$ of England - see here: https://www.bankofengland.co.uk/statistics/ yield-curves
}

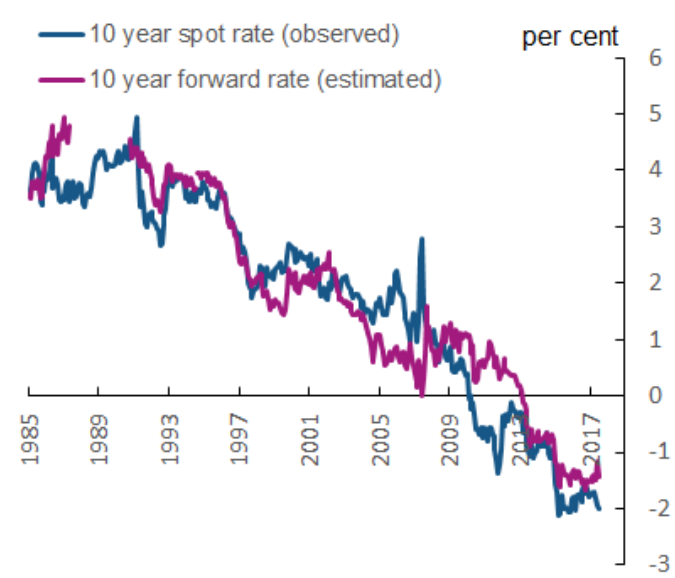

Figure 6: 10 year index-linked gilt yield and the 10 year index-linked gilt expected in 10 years' time (1986-2018) 
One factor for house price dynamics is the extent to which the decline in the risk-free rate was expected by markets. If market participants had perfect foresight of the trajectory of the index-linked yields, then we would expect house price movements to reflect that expected future path and not to feature sharp adjustments. The growth in house prices would then be relatively smooth, and consistent over time, with some of the impact of low real interest rates in the future already reflected in prices at the beginning of the period.

We find evidence in the yields data that strongly suggests investors consistently thought real yields - despite having fallen steadily over the past 35 years - were not going to change much from whatever level they had reached. At each point, the then-current spot rates on 10 year index-linked gilts were consistently close to anticipated rates ten years ahead, where the latter are measured by using the 10 year and 20 year index-linked yields at each point in time to create a measure of the implied forward rate (see Figure 6). The path of forward rates is almost indistinguishable from the path for spot rates, implying that investors consistently believed real bond yields would stay at around current levels. The average 10 year real spot rate across the period is $1.6 \%$, whilst the average forward rate is $1.7 \%$. This is inconsistent with people anticipating a downward trend in real rates; that would have meant that forward rates were consistently below spot rates.

A simple time series regression to estimate the average relation between the 10 year spot rate and the 10 year ahead forward rate reinforces this: the co-integrating relation between the 10 year index-linked yield and the 20 year index-linked yield implies a steady-state real rate of $2.6 \%$. However, the end-2018 rate was $-2.0 \%$. Once again this suggests the fall in real yields over past decades was not anticipated

While we believe that there is strong evidence that the scale of falls in interest rates was very largely unanticipated, we should stress that even if it had been anticipated it would still have generated a very large rise in house prices over time. We illustrate this below with a comparison of house prices under perfect foresight about real interest rates and under the alternative assumption (which we think the evidence supports) that at each point real rates are expected to remain at their latest level.

Falls in real interest rates are a global phenomenon. King and Low (2014) present a measure of

\footnotetext{
${ }^{6}$ Nor is this finding restricted to people's expectations of the future 10 year rate. Estimating the 5 year forward rate - that is the implied expected 5 year index-linked yield in 5 years' time (based on the 5 year and the 10 year index-linked yields) produces the same conclusion - people consistently seemed to expect the 5 year index-linked gilt yield in 5 years' time to be about the same as it was at that point in time.
} 
a 'world' interest rate, using data for 10 year index-linked bond yields for G7 countries (excluding Italy, due to Italy's rates experiencing significant volatility as a result of the euro area crisis). Summers and Rachel (2019) extend this measure to 2018. Figure 7 reproduces their chart. The fall in global real interest rates is most unlikely to have been caused by developments in the UK housing market; it is plausibly best seen as a largely exogenous driver of house values. We return later to the important question of what drove real rates lower later, and whether it can be seen as exogenous - and causal - for UK house price movements.

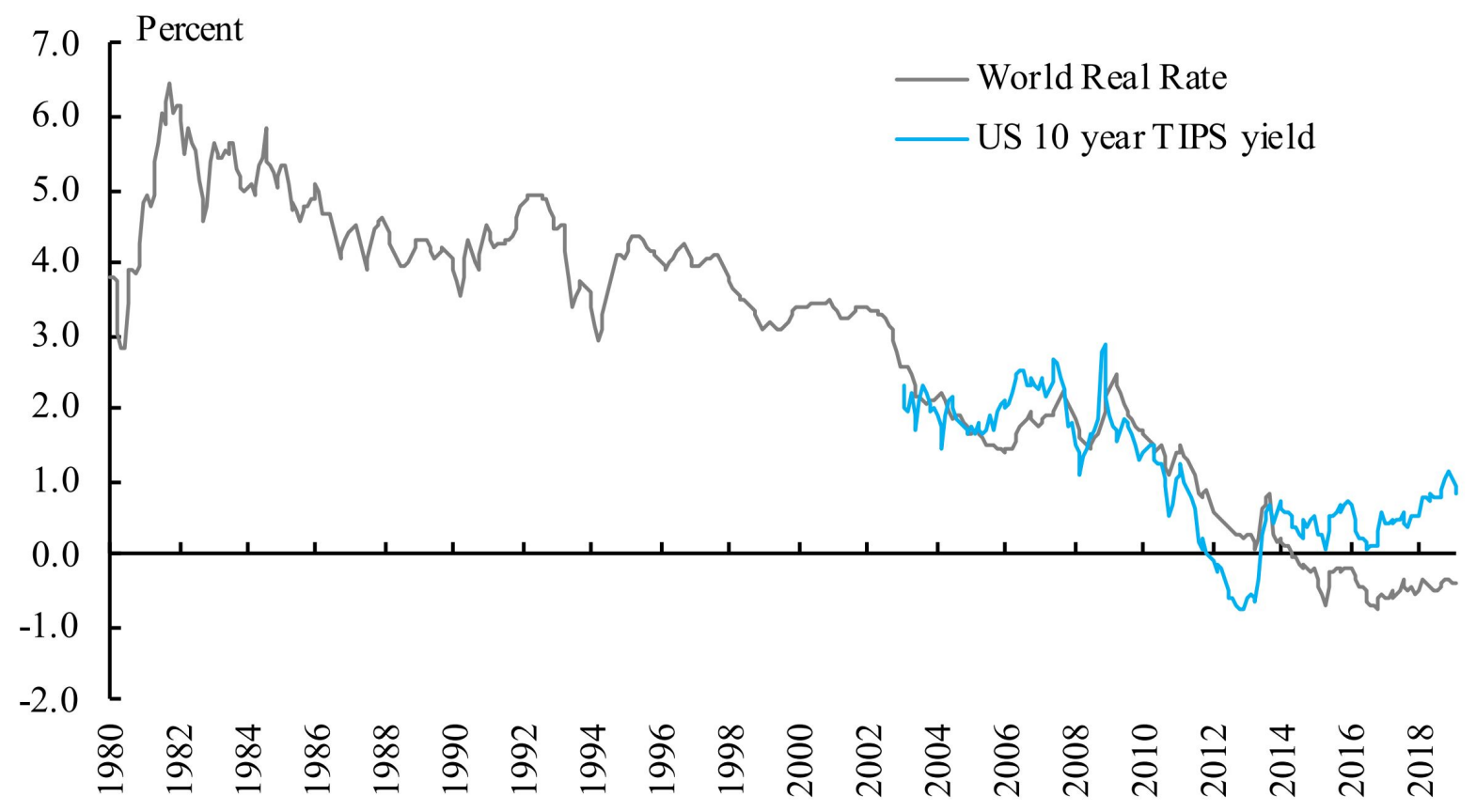

Figure 7: Summers and Rachel (2019): World interest rate - weighted average 10 year index-linked yields for G7 countries (excl. Italy)

Next we turn to expected real capital gains on housing, another key component of the user cost of housing. Here we proceed by assuming that $\delta_{t}+P O_{t}+R P_{t}$ (i.e. the sum of maintenance, taxes on property ownership, and the risk premium on housing) has been relatively constant and see what conclusion that generates about $E\left[\rho_{t}\right]$, the expected capital gains. We then check for consistency by modelling house prices on that assumption and allowing for supply and demand elasticities for housing. The key idea is that if: (a) $\delta_{t}+P O_{t}+R P_{t}$ is roughly constant and (b) at each point in time people thought that the average future level of the safe real rate is today's level then, in a fundamental equilibrium, expected real house price growth will be approximately equal to expected growth in real rents. 
This reflects the well-known condition implied by Equations 2 and 3 that, absent a bubble, real house prices equal the present value of expected future rents. These equations imply the appropriate discount rate for the present value calculation in each future period $i$, is:

$$
R_{(t+i)}+\delta_{(t+i)}+P O_{(t+i)}+R P_{(t+i)}
$$

If, at each point in time, each of the components of this discount rate (including future safe real rates) are expected to be constant then real house prices will only be expected to change in the future as a result of expected changes in real rents.

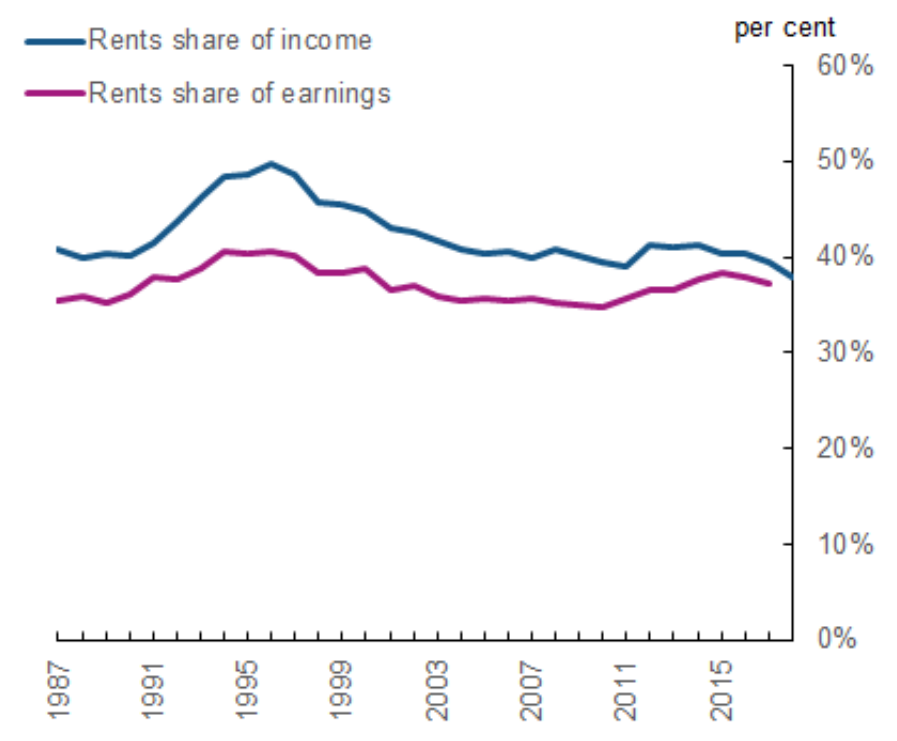

Figure 8: Average annual rents as a proportion of average disposable household income (on an equivalised basis) and average gross earning $\$^{a}$

\footnotetext{
${ }^{a}$ Data on rents is estimated as the product of the rental yields series (see Figure 2) and the ONS UK house price index. Income and earnings series are those presented in Figure 3.

How much might reasonable people have expected real rents to grow? Figure 8 suggests a clear answer. They show that average rents in the UK have been stable relative to both incomes and earnings (using the same measures of income and earnings as was used in Figure 3) $!^{7}$

${ }^{7}$ This is broadly consistent with other data. The UK Housing Review 2019 data includes a series of all private rents as a ratio to earnings. The series is much shorter than the period we consider, but they indicate that the ratio has been relatively consistent over time, although the levels are lower than we estimate and there is some variation by region. Joyce, Mitchell and Norris Keiller (2017) consider the median weekly rents and incomes of private-renting households in Britain (excluding London), and show that whilst there was an uptick in the ratio between 1994 and 1999, from 1999-2015 the two measures seem to move approximately in parallel.
} 
Thus a rational expectation would plausibly have been that average real rents would grow at around the growth rate of real incomes. This means (conditional on the assumption that, at each point in time, the risk-free rate, property ownership taxes, maintenance and the risk premium were expected to be roughly the same for all future periods) house prices would have been expected to grow in line with average future real incomes. Furthermore, a reasonable anticipation of average future real income growth might plausibly have changed rather little over time. The evidence from vector autoregressions presented below is consistent with this; it shows that house prices respond around one for one to shocks to real incomes and that such shocks to real incomes are persistent.

This set of assumptions has the following implication: as the risk-free rate, $R_{t}$, fell (at every point in a way that was largely not anticipated, not expected to be reversed but also not expected to be followed by further falls) house prices would rise more sharply than had previously been expected and rental yields would fall in a way that followed the safe real return lower.

This is consistent with what has happened in the UK. Figure 9 suggests that rental yields have indeed fallen in line with index-linked yields. This is what Equation 5 leads one to expect. The gap - or 'wedge' - between the two has averaged 6.4\%. Equation 5 shows that this wedge should be equal to the average value of $\delta_{t}+P O_{t}-E\left[\rho_{t}\right]+R P_{t}$.

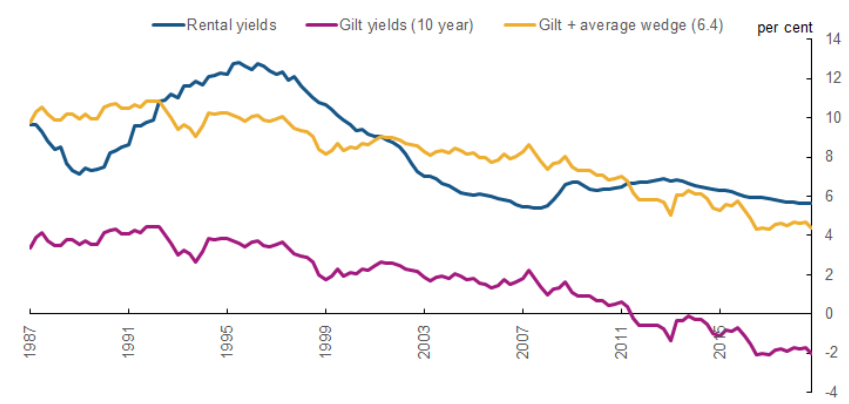

Figure 9: Comparison of the rental yield to the 10 year index-linked gilt yields

\section{Verifying the assumptions}

Is it plausible that the average cost of maintaining a property, paying the necessary taxes and the risk premium - net of expected real capital gains - could come to around 6\%, as implied by Figure 9, and as needs to hold to be consistent with Equation 5?

Consider each of the components:

- The average annual cost of overall maintenance of a residential property $(\delta)$ is plausi- 
bly around $2 \%$ of the value of the house $\square^{8}$ If we add an estimate of insurance costs, an overall maintenance and depreciation charge of the order of $2 \%-3 \%$ of property value is reasonable.

- Over the time horizon considered by this paper, there have been two notable developments in the tax treatment of property ownership $(P O)$. First, stamp duty on land and property has become a significantly more important tax, with a number of reforms to its application across the period. This includes moving from applying a single rate of tax on the entire property price (a 'slab' basis), to applying different tax rates to portions of a property price (a 'slice' basis, akin to income tax). Moreover, stamp duty land tax has been updated to advance different policy aims - including encouraging first time buyers. As at Q1 2019, the rate of stamp duty due on a residential property transaction depended on, for example, the price of the property, the type of borrower (first time buyers have a limited exemption), and whether the purchaser holds existing properties. In 1998, ONS data indicates nominal stamp duty (land and housing) tax receipts of $£ 2.7 \mathrm{bn}$, including commercial receipts compared to $£ 12.9 \mathrm{bn}$ in receipts for 2018.9 This far outpaces nominal growth in average residential housing values, which have tripled over the same period. But stamp duty is a very small amount of the overall value of housing stock - Savills estimate the total value of residential housing at $£ 7.29$ tn in 2018 , implying that annual stamp duty receipts (including commercial receipts) accounted for $0.18 \%$ of housing values (2019). HMRC data on the breakdown of stamp duty receipts by commercial and residential properties indicate that residential receipts comprise $60 \%-75 \%$ of total receipts across the period 2007-2018 10 This provides a proxy for the upper limit of an estimate for residential stamp duty receipts $0.13 \%$ of residential property values. At the same time, mortgage interest relief for owneroccupiers has become obsolete over the period. The cost of mortgage interest relief peaked in $1990 / 91$, at $£ 7.7 \mathrm{bn}$ in nominal terms; it was abolished in full by 2000.11 Stamp duty and mortgage interest relief are, individually, relatively small compared to the aggregate value

\footnotetext{
${ }^{8}$ There is a good deal of evidence on the depreciation of residential structures: Fraumeni (1997) finds a depreciation rate of between 1.5-3\% each year; Van Nieuwerburgh and Weill (2010) simulate house price dispersion using a depreciation rate of 1.6\%; Harding, Rosenthal and Sirmans (2007) suggest depreciation net of maintenance is $2.5 \%$. Himmelberg et al (2005) assume a value of $2.5 \%$.

${ }^{9} \mathrm{ONS}$ series MM9F, current receipts from taxes on production - stamp duty, land and housing.

${ }^{10}$ Based on stamp duty land tax transactions of $£ 40,000$ or more.

${ }^{11}$ HMRC data on mortgage interest relief is available on the National Archives. See, for example, here: https:
} 
of residential property. ${ }^{12}$

- Measures of the housing risk premium, $(R P)$ are a challenge to pin down. Jordà et al (2019) show that real returns on housing over the very long term are comparable to those of equities. If the return on houses were also perceived as being as risky as that of a diversified portfolio of equities, then the premium might be $4-6 \%$ per annum (this being a plausible estimate of the risk premium on equities). They show that aggregate house price volatility is significantly smaller than is equity return variability. But the price of individual homes is far more volatile than the return on a diversified portfolio of equites. Case et al. (2005) estimated that it was twice as volatile for the US. Even so houses are likely seen as somewhat less risky than equities - in part because, even if their sensitivity in price to aggregate economic factors is likely to be high, they help hedge against future rises in house values and rents. For a borrower, one component of the risk premium is the mortgage rate spread to the risk-free rate. This has shown significant variability from year to year but no obvious trend. Across the period 1997-2018, the average mortgage spread on new loans relative to a reference rate was around 150bps (see Figure 10). Overall an average mortgage spread, $R M$, of around $2 \%$ on the stock of mortgages looks plausible and a figure of $3-4 \%$ for the risk premium on housing, $R P H$ (i.e. between half and two thirds of that of equities). Our composite risk premium term reflects the gap between a safe rate and a measure of funding costs that reflects a mix of own funds (with an opportunity cost) and debt. But own funds are much larger than debt for the typical UK home-owner and so the housing risk is more relevant than a mortgage spread. Such a premium is plausibly in a range of $3-4 \%$.

We argued above that expected capital gains reflect the expected growth in rents, which is closely linked to the expected growth in incomes. Average growth in aggregate disposable household income, which factors in growth in household numbers, is around $1.8 \%$ across the period.)

Adding these up, a plausible range for $\delta_{t}+P O_{t}-E\left[\rho_{t}\right]+R P_{t}$ is around $4-6 \%$, slightly below the average gap of just over 6\% shown in Figure 10, though not obviously inconsistent with it.

//webarchive.nationalarchives.gov.uk/20121106040152/http://www.hmrc.gov.uk/stats/mir/menu.htm

${ }^{12}$ But they have not been constant. Over the relevant time horizon, homeowners both faced increasingly higher taxes on purchasing property and decreasing capacity to offset interest on their mortgage from their personal tax bill. In our final results, we estimate the approximate impact of these changes on long-run house prices. 


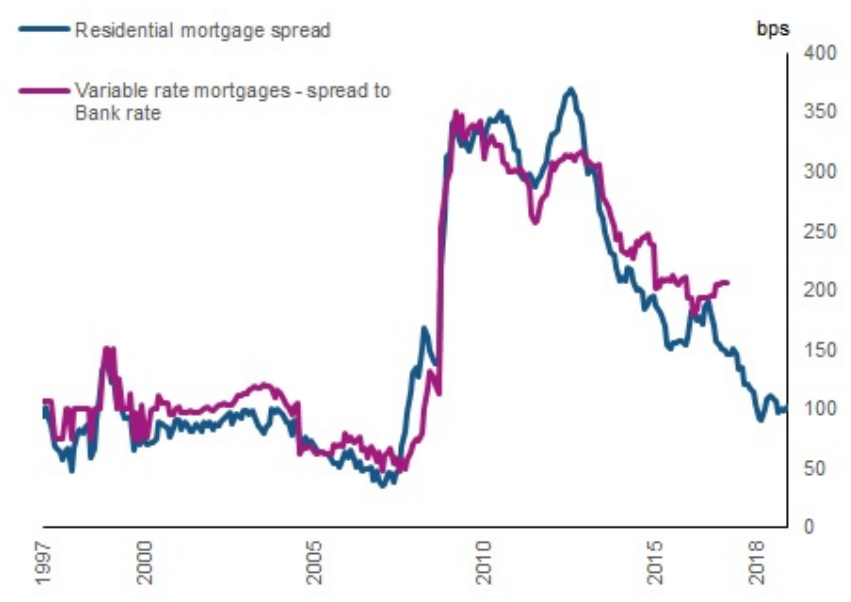

Figure 10: Spread of residential mortgage quoted rates to the risk-free rate (bps a $_{4}$

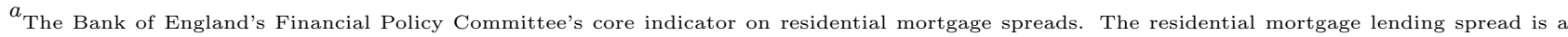
weighted average of quoted mortgage rates over risk-free rates, using 90\% LTV two-year fixed-rate mortgages and $75 \%$ LTV tracker, two and five-year fixed-rate mortgages. The variable rate mortgages spread series comes from the Bank of England data series 'A Millennium of Data'.
}

\section{The drivers of house prices}

We begin by considering the immediate (short-run) effect of unanticipated changes in real interest rates. In the short run the stock of housing is fixed, so equilibrium requires that house prices shift such that overall demand for housing (from owner-occupiers and renters) is unchanged.

Taking logarithms of Equation 4, we have:

$$
\ln \left(P_{t}^{H}\right)=\ln \left(R R_{t}\right)-\ln \left(R_{t}+\delta_{t}+P O_{t}-E\left[\rho_{t}\right]+R P_{t}\right)
$$

If rents and user costs do not suddenly change after an unanticipated shift in real interest rates (that is not expected to be reversed) then demand for owner-occupied or rented property would be unchanged - and with unchanged supply that would constitute the new (short-run) equilibrium.

Equations 2 and 7 imply that, with unchanged rent and in order to keep the user cost of housing constant ${ }^{13}$ we require:

$$
\Delta \ln \left(P_{t}^{H}\right)=-\Delta \ln \left(R_{t}+\delta_{t}+P O_{t}-E\left[\rho_{t}\right]+R P_{t}\right)
$$

In evaluating the right hand side of Equation 8, the only component that would change when real interest rates shift is the direct effect of a move in the risk-free interest rate $\left(R_{t}\right)$ - provided that people expect future real interest rates and other components of cost to be then unchanged,

\footnotetext{
${ }^{13}$ Here we ignore any random component of changes in house values not related to the equilibrium conditions.
} 
and anticipate rents to keep rising in line with incomes (whose average rate of growth is likely to be rather insensitive to shifts in medium-term real rates). We find this assumption consistent with the time series evidence we present below. In this case there would be no shift in expectations of the change in future real house prices (so that $E\left[\rho_{t}\right]$ - the expected capital gain - does not change). Current house prices do all the adjustment.

Over a longer horizon, the rise in prices caused by an unanticipated fall in real yields might generate some extra housing supply. Factoring this in would potentially make inconsistent the assumption that in future prices and rents rise in line with incomes only. But all the evidence suggests that housing supply in the UK is not very responsive to price, though any supply response would make the longer term impact of unanticipated falls in real interest rates somewhat less than the short-run response. We now explore how significant this effect could be, and whether long-run and short-run price changes could be significantly different.

In equilibrium the change in housing supply $\left(H^{s}\right)$ must match the change in housing demand $\left(H^{D}\right)$. The relevant measure of cost for the demand side is the user cost. From Equation 2, and taking differences in the natural log:

$$
\Delta \ln \left(U C H_{t}\right)=\Delta \ln \left(P_{t}^{H}\right)+\Delta \ln \left(R_{t}+\delta_{t}+P O_{t}-E\left[\rho_{t}\right]+R P_{t}\right)
$$

Demand will also change as a result of income changes - which we assume drive changes in both the demand for owner occupied housing and rental housing (with an equal income elasticity of demand of $\epsilon_{y}$ ).

Putting these ideas together, we specify the long-run percentage change in supply $\left(H^{S}\right)$ and demand $\left(H^{D}\right)$ for housing are given, respectively, as:

$$
\Delta \ln \left(H^{S}\right)=\phi+\epsilon_{s} \cdot \Delta \ln \left(P_{t}^{H}\right)
$$

and

$$
\Delta \ln \left(H^{D}\right)=\epsilon_{y} \cdot g_{y}+\epsilon_{d}\left[\Delta \ln \left(P_{t}^{H}\right)+\Delta \ln \left(R_{t}+\delta_{t}+P O_{t}-E\left[\rho_{t}\right]+R P_{t}\right)\right]
$$

where $\epsilon_{s}$ is the elasticity of supply of the housing stock with respect to price; $\epsilon_{d}<0$ is the elasticity of demand with respect to the user cost; $\epsilon_{y}$ is the income elasticity of demand for housing and the change in aggregate log incomes is denoted by $g_{y}$. (Since we focus on aggregate demand for 
housing it is the change in aggregate household disposable income - and not in average household real disposable income - that is relevant.) $\phi$ is a constant representing that part of the rise in the stock of housing independent of house prices. We shall assume that government policy (for example, on zoning restrictions and the granting of house building permits) is for the supply of new homes (at unchanged real house prices) to match a fraction of extra demand. This implies that $\phi=\alpha\left(\epsilon_{y} g_{y}\right)$, where $\alpha$ is the fraction of extra demand coming from rising incomes that can be matched by supply. In the UK the supply of new homes has consistently fallen short of projections of demand for new homes for many years, so it is plausible that $\alpha$ has been persistently below 1 , and it has shown no signs of rising.

Setting these two expressions (Equations 10 and 11) equal to each other implies:

$$
\Delta \ln \left(P_{t}^{H}\right)=\frac{\epsilon_{y}(1-\alpha)}{\epsilon_{s}-\epsilon_{d}} g_{y}+\frac{\epsilon_{d}}{\epsilon_{s}-\epsilon_{d}} \ln \left(R_{t}+\delta_{t}+P O_{t}-E\left[\rho_{t}\right]+R P_{t}\right)
$$

Comparing Equation 9 to Equation 12 shows that the difference between the short-run and long-run change in house prices is that in the longer term changes in income matter and the reaction to an unexpected change in real rates that is nonetheless expected to be permanent is $\frac{\epsilon_{d}}{\epsilon_{s}-\epsilon_{d}}$. This will be less than 1 in absolute value if $\epsilon_{s}>0$.

\section{Looking beyond short-run effects by allowing for supply and incomes to change}

The value of the price elasticity of supply of the stock of housing is central to the question of whether long-run changes in house prices differ substantially from short-run changes. Estimates of this price elasticity (of the supply of the stock of housing) in the UK are relatively low - often virtually indistinguishable from zero. Meen (2005) suggests that since the 1990s, the regional supply elasticities in the UK have been very low - he estimates the long-run housing stock supply elasticity for England is insignificantly different from zero. Some papers look specifically at the supply elasticity of new housing investment: e.g. Swank et al (2002) report a price elasticity of supply for new housing of 0.45; OECD (2011) suggest the long-run price elasticity of supply of housing investment for the UK is around 0.4. Since the stock of housing is vastly greater than the level of new housing (i.e. investment) the elasticity of the stock, which is the relevant variable for house prices, is a small fraction of 0.4 . If the flow of investment in a year is $1 \%$ of the stock and the flow elasticity is 0.4 , then the short-run stock elasticity would be 0.004 . 
In recent years in England, house building has barely reached 200,000, compared to an existing housing stock of around 22 million residential properties. So building is just under $1 \%$ of the stock of housing. Applying a price elasticity of new building volumes of 0.4 to a $1 \%$ increase in house prices amounts to just 800 more houses built - even across a 20 year horizon, that is a mere 16,000 new houses built, or slightly under 0.0008 of the existing stock. This is equivalent to a stock elasticity after 20 years of 0.08 - the value we use in the remainder of this paper. At such a low stock elasticity, people would be rational to believe that the amount of housing is effectively unchanged by house price changes.

Very low price elasticities of the stock of housing are implied by the sluggish response of UK housebuilding to a long period of high and rising house prices. There is little evidence to suggest that the provision of housing services per capita has increased in the long run. Whilst crude measures of the number of properties per capita have increased, this aggregate statistic masks two key underlying trends: the greater building of flats rather than houses, and the smaller size of new builds. The English Housing Survey 2016 ${ }^{14}$ stock condition data suggests the prevalence of flats (converted or purpose built) in the overall stock has increased from 19\% in 1996 to $21 \%$ in 2016.

Williams (2009) finds that new houses built in the UK were smaller than the existing stock average stock size was $87 \mathrm{~m}^{2}$ compared to a new build size of $83 \mathrm{~m}^{2}$. Estimates provided by the Royal Institute of British Architects and also by companies involved in new-build construction indicate that rooms are smaller in new builds, with many properties not meeting minimum space standards ${ }^{15}$ And Morgan and Cruickshank (2014) connect the small, and declining, house size of UK homes with under-occupation of homes. So overall the supply elasticity of the stock of housing in the UK is small, and probably smaller than most other G7 countries. It may seem a strong assumption to make that this elasticity has been constant over the past several decades. But a substantial factor behind supply elasticity has been fairly constant: the planning regime for permitted developments. This system was put in place with the Town and Country Planning Act of 1947, and which is still in place in 2020 (though proposed radical changes were announced in August 2020).

Estimates of the price elasticity of demand are typically much larger (in absolute magnitude) than the elasticity of supply, but are well short of unity. Muellbauer and Murphy (1997)

\footnotetext{
${ }^{14}$ The English Housing Survey 2016 report and data is available here: https://www.gov.uk/government/ statistics/english-housing-survey-2016-stock-condition

${ }^{15}$ See Royal Institute of British Architects (2015) and LBC Warranty (2019).
} 
estimate the price elasticity at -0.52, Muellbauer (2018) uses a value of -0.5. Other estimates of the price elasticity are slightly greater at between -0.5 and -0.8 ; see, for example Ermisch et al. (1996) who put the range at between -0.5 and -0.8, or Rognlie (2016) who finds a slightly larger range for the elasticity - between -0.4 and -0.8 .

Average estimates across developed countries of the income elasticity of demand tend to be lower than estimates for the UK. Malpezzi and Wachter (2012) suggest that micro-studies typically generate estimates in the $0.5-0.8$ range, whilst aggregate studies tend to produce elasticities closer to unity, as they capture the long-run dimension of behaviour. Muellbauer and Murphy (1997) estimate an income elasticity of housing demand of 1.32, and Meen and Andrew (1998) estimate an income elasticity of 1.27 .

Plausible values of the three key elasticities might therefore be:

$$
\begin{aligned}
& \epsilon_{s}=0.08 \\
& \epsilon_{d}=-0.6 \\
& \epsilon_{y}=1.3
\end{aligned}
$$

With an income elasticity of demand of 1.3, real disposable income growth for the household sector in aggregate of around 1.8\%, and housing building growing the stock by not even $1 \%, \alpha$ (the fraction of extra demand coming from rising incomes) is at most around 0.5.

Plugging these values into Equation 9 generates a long-run process for house price changes:

$$
\Delta \ln \left(P_{t}^{H}\right)=\frac{1.3(1-0.5)}{0.08-(-0.6)} \cdot g_{y}+\frac{-0.6}{0.08-(-0.6)} \cdot \Delta \ln \left(R_{t}+\delta_{t}+P O_{t}-E\left[\rho_{t}\right]+R P_{t}\right)
$$

which is approximately equal to:

$$
\Delta \ln \left(P_{t}^{H}\right)=g_{y}-0.9 \cdot \Delta \ln \left(R_{t}+\delta_{t}+P O_{t}-E\left[\rho_{t}\right]+R P_{t}\right)
$$

This would imply that in the long run house prices rise in line with incomes less around $90 \%$ of any increase in $\left.\ln \left(R_{t}+\delta_{t}+P O_{t}-E\left[\rho_{t}\right]+R P_{t}\right)\right]$.

Changes in $\ln \left(R_{t}+\delta_{t}+P O_{t}-E\left[\rho_{t}\right]+R P_{t}\right)$ are very likely to have been dominated by the change in $R_{t}$, the risk-free rate, which we have argued are unanticipated. The long-run impact of changes in real interest rates we estimate at about 0.9 times as large as the short-run impact, but this is based on an assumed price elasticity of the stock of housing as high as 0.08 - a figure only likely to be achieved around 20 years after an initial rise in house prices. We conclude that it would be reasonable for anyone to essentially assume that the short-run and long-run impact on 
house prices of a change in real interest rates that is expected to be permanent is effectively the same over any plausible investment horizon.

\section{Accounting for the UK experience over three decades}

Equations 8 and 14 show the short-run and long-run drivers of house prices. We use those relations to estimate how much income growth and changes in real interest rates - both fundamental factors - might have contributed to the growth in house prices. 16

As noted earlier, the average value for $\delta+P O-E[\rho]+R P$ between 1987 and 2018 Q3 is around 6.4\%. If we assume for the moment that all these components are at their average value and that the real gilt yield falls by 1 percentage point from an initial value of 0 then $R_{t}+\delta_{t}+P O_{t}-E\left[\rho_{t}\right]+R P_{t}$ falls to $5.4 \%$. In the short-run income growth is unchanged, and so a 1 percentage point decrease in real gilt yields implies a short-run change in log house prices of +0.169 ; as a percentage this is 18.4\%. It is clear from this simple calculation that real interest rate changes on the scale seen in the UK over the past 35 years have the potential to have driven up house prices by large amounts.

Table 1 computes the effect on house prices of changes in the safe real rate of interest between 1985 and 2018. For the moment, we assume that the average wedge between the real gilt yield and the overall percentage user cost of housing of $6.4 \%$ applies in all periods.

The table suggests that, in the absence of any supply response, structural changes in the user cost of housing from declines in real interest rates resulted in a $127 \%$ increase in real house prices. Over this period there is some evidence of a slight net increase in mortgage spreads of perhaps $0.2 \%$ or so; if we accounted for that, the impact of interest rate changes on real house prices would be a bit lower at about $115 \%$.

At the end of 2019, the real yield on a 10 year index-linked gilt was $-2.4 \%$. A 1 percentage point increase in gilt yields that was assumed to be persistent would be associated with a fall in equilibrium real house prices of approximately 20\%. Were real gilt yields to rise to $0 \%$ (levels last seen around 2011), this would imply a $37 \%$ fall in real house prices.

The calculation above suggests that the change in real rates over the period since the mid 1980s may have roughly doubled house prices. This is based on the assumption that the change

\footnotetext{
${ }^{16}$ All series showed in this section are adjusted for RPI. In terms of CPI, growth would be approximately $1 \%$ higher per year.
} 
in rates was consistently unexpected. Had the scale of falls in rates been perfectly anticipated at the start of the period house prices would have been higher at the beginning but would have ended in the same place if people now thought rates would no longer continue to decline. A simple calculation helps show the scale of the difference this makes. Suppose we set other components of the user cost besides the interest rate at a constant level - equal to our average "wedge" of 0.064 . Suppose also real rents were flat, at $R R$. The house price at each instant on the assumption of no anticipation of any change in future interest rates from a current level of $R_{t}$ is simply $\frac{R R}{R_{t}+0.064}$. If people correctly saw the path of rates from the outset (but which by 2018 was no longer expected to fall further) the house price would have to satisfy the equation: $P_{t}=\frac{E\left(P_{t}+1\right)}{1+R_{t}+0.064}+R R$. We can use that equation to work out a path of prices if we fix an end point and, to do that, assume that by 2018 real rates had fallen to a level they were no longer expected to fall further. Thus $P_{2018}=\frac{R R}{R_{2018}+0.064}$ on both the myopic and perfect foresight path. Assume that since 1985 real rates fell steadily from +0.04 to -0.015 - which is a $5.5 \mathrm{pp}$ decline that roughly matches what happened in the UK. Under the myopic path house prices would then have risen by just over 100\%. On the perfect foresight path they would have risen by about $63 \%$ - which means they would have been about $23 \%$ higher in 1985 than under the myopic assumption.

Now we assess whether allowing for a supply response and for some changes in taxes over time significantly alter these estimates.

Table 2 shows that factoring in a change in supply induced by higher house prices somewhat dampens the impact of a change in real interest rates. We also account for an approximate impact of changes in the tax system for property ownership - namely, the increasing importance of stamp duty and the declining importance of mortgage interest relief. ${ }^{17}$ These tax changes offset a small part of the impact of falling real gilt yields - reducing the overall impact of all factors besides income growth to about 93\%; our estimate of the gilt yield impact on its own is about $109 \%$.

The tables show that, in sub-periods within the three decades we are exploring, the relationship breaks down. There are two possible explanations for this: (i) our assumption that the other elements in the user cost are constant over the time may be plausible across the full period, but mask important variation between the pre-crisis and post-crisis period; and/or (ii) while changes

\footnotetext{
${ }^{17}$ We caveat that our analysis of the changes in taxation over the period is likely to overstate its impact - we do not have data on stamp duty for the beginning of the period, and due to the volatility of the series, we do not attempt to impute values. This means the level of housing taxation we assume at the beginning of the period is lower than it would actually have been, because it does not incorporate stamp duty.
} 
in the user cost play the dominant role in driving house prices over the longer term, in the shortterm, other factors are more strongly associated with changes in UK house prices. In the next section we provide evidence for an important and relevant difference in the risk premium in the two sub-periods we look at, and that can account for much of this difference. However, we still believe the second explanation to be relevant: for example, we noted in Section II that lack of credit availability does not undermine the model's key assumptions for the long-term relationship. In the short-run, however, it is plausible for credit conditions to affect house prices and for this to be a very relevant factor in the immediate pre-crisis and post-crisis periods. Consider the case of a sudden negative shock to credit availability: some people are forced to rent though would ideally like to purchase a home ('reluctant renters'). The housing market clears: properties that the reluctant renters would have purchased are instead purchased by landlords. This has consequences for rents - both anticipated and actual - particularly if reluctant renters go on to rent smaller properties (i.e. buy fewer housing services) than they might otherwise have purchased. 
Table 1: The effect of the decline in the risk-free rate on house prices - no supply response

\begin{tabular}{|l|l|l|l|}
\hline Period & $\begin{array}{l}\text { Change in gilt yields across period } \\
\text { (percentage points) }\end{array}$ & $\begin{array}{l}\text { Implied effect on log house prices of } \\
\text { change in gilt yields } \\
\text { (delta log term - see Equation 7) }\end{array}$ & $\begin{array}{l}\text { Implied change in real house prices } \\
\text { (per cent) }\end{array}$ \\
\hline $1985-2018$ & -5.6 & 0.82 & $127 \%$ \\
\hline $1985-2008$ & -2.2 & 0.25 & $29 \%$ \\
\hline $2008-2018$ & -3.4 & 0.57 & $76 \%$ \\
\hline
\end{tabular}

Table 2: The effect of the decline in the risk-free rate on house prices - allowing for a supply response

\begin{tabular}{|l|l|l|l|l|l|}
\hline \multirow{2}{*}{$\begin{array}{l}\text { Period } \\
\text { due to changes in gilt } \\
\text { yields } \\
\text { (per cent) }\end{array}$} & $\begin{array}{l}\text { Growth in house prices } \\
\text { prices due to } \\
\text { tax changes } \\
\text { (per cent) }\end{array}$ & $\begin{array}{l}\text { Growth in house } \\
\text { real income to rising aggregate } \\
\text { (per cent) }\end{array}$ & $\begin{array}{l}\text { Combined: growth in house prices } \\
\text { due to falling gilt yields, tax } \\
\text { changes, and real incomes } \\
\text { (per cent) }\end{array}$ \\
\hline $1985-2018$ & $109 \%$ & $-16 \%$ & $83 \%$ & $176 \%$ & $153 \%$ \\
\hline $1985-2008$ & $26 \%$ & $-8 \%$ & $71 \%$ & $89 \%$ & $184 \%$ \\
\hline $2008-2018$ & $67 \%$ & $-2 \%$ & $6 \%$ & $72 \%$ & $-11 \%$ \\
\hline
\end{tabular}


Table 2 shows that rising incomes, falling real interest rates and changes in tax treatment account for slightly more than the overall rise in real house prices over the last three decades (176\% versus an outturn of $153 \%$ ). There is one additional cost not allowed for here, which plausibly accounts for the slight over-prediction of house price growth in the results - there has been a slight increase in the mortgage spreads to the risk-free rate. Some evidence for this increase is provided above (see Figure 10), though we note that this reflects pricing on new mortgages, rather than the stock. We estimate that the net effect across the period might be in the region of an increase in costs of 20-30bps. This would generate expected growth in house prices due to incomes rising, tax changes, gilt yields falling and a small increase in mortgage spreads of between $161 \%$ and $164 \%$ - not far off the observed growth in UK national house prices.

\section{What makes the first half of our time period so different to the second?}

Table 2 showed that whilst our model matches the rise in prices for the full period, it does not explain the pre-crisis and post-crisis changes in house prices very well. In the pre-crisis period it underpredicts house price growth, but overpredicts house price growth in the post-crisis period.

This can be explained within the model if the 'wedge' in the user cost - i.e. the components other than the gilt yield in the user cost - are not constant across the period, as assumed so far. In this section, we allow for change in the risk premia before and after the global financial crisis. There is a great deal of evidence that risk premia on a wide range of assets changed after the onset of the crisis. We present evidence that the risk premium heading into the crisis was materially lower than the risk premium towards the end of 2018 - perhaps by as much as 200bps. This net rise in the risk premia over the period since just before the financial crisis can account for the overprediction of house prices since 2007 when no allowance for this is made.

Figure 10, presented earlier, provides an indication of how the risk premium on mortgage lending has evolved since 1997. A gentle decline in the spread on new mortgages can be observed in the period prior to the crisis, taking the spread down to just under 50bps by 2007. By the end of the post-crisis period, much of the explosion in spreads that came after the crisis had unwound, but were still a bit more than 50bps above the level in 2007.

Figures 11 to 14 provide some evidence on the risk premium on deposits, UK equities and corporate bonds respectively.

Figure 11 shows the the spread of the average UK interest rate charged by financial institutions 
to households on term deposits of less than 1 year maturity to the Bank of England's policy rate. The post-crisis period again shows a clear increase in the implied risk premium in net terms, in the order of $50 \mathrm{bps}$.

For equities, we take the spread of the earnings yield (i.e. the earnings to price ratio) for each of the FTSE 100, FTSE 250 and FTSE All-Share to the 10 year index-linked gilt yield used in this paper (Figure 12). Comparing data in the last half of 2007 to data for the last half of 2018 implies an increase in the risk premium of 200-300bps; the average risk premium in the pre-crisis period is clearly considerably lower than that of the post-crisis period.

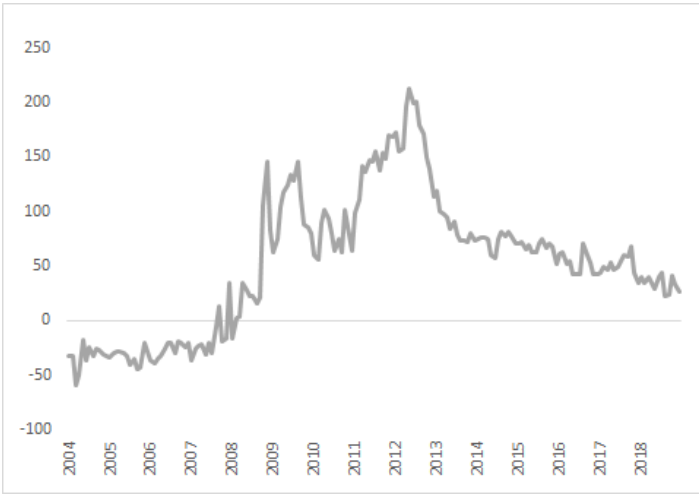

Figure 11: Spread of the weighted average short term (less than 1 year) maturity deposit rates set by UK deposit-takers for households to Bank of England base rate. ${ }^{a}$

\footnotetext{
$a_{\text {Data on deposit rates is from the Bank of England's Bankstats }}$ database, series "CFMBI84", available online. The Bank also publishes the historical Bank rate.
}

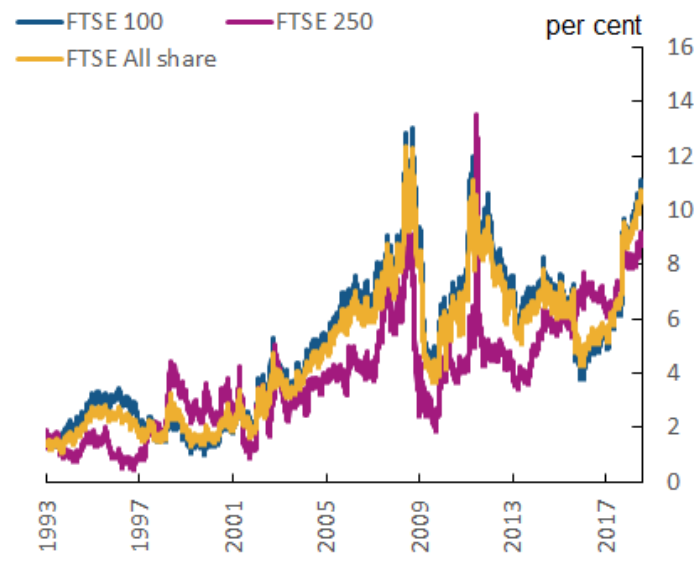

Figure 12: Spread of the inverted price to equity ratio for the FTSE 100, FTSE 250, and FTSE All-Share to the 10 year index-linked gilt yield.$^{a}$

$a_{\text {Price to equity data comes from Bloomberg. }}$

In the corporate bond market, the evidence suggests marginal increases in risk premia in the post-crisis period. For UK corporate bonds, the Bank of England's Financial Stability Report from June 2018 shows a measure of sterling investment-grade corporate bond, decomposed into the spread above the risk-free rate. In net terms, the risk premia between 2007 and 2018 does not appear to have changed significantly - but this masks a significant widening, followed by a narrowing, which suggests that the average risk weight over the period was much larger than the preceeding, pre-crisis period.

Figures 13 and 14 provide some sense of the risk premium for international corporate bonds. Figure 13 shows the Federal Reserve Bank of St. Louis' measures of the spread of US corporate bonds to the 10 year US Treasury (both Moody's seasoned Aaa and Baa bonds). In both cases, 
there has been little movement in the risk premium between the second half of 2007 and the second half of 2018, but the data - which spans the full pre-crisis and post-crisis period - implies that the average risk premium for each series was in the order of 100bps greater in the postcrisis period than in the pre-crisis period. The Federal Reserve's Financial Stability Report from November 2019 also shows how the spreads on newly issued institutional leveraged loans (i.e. new loans to corporates that were already significantly indebted) have evolved over time: this spread also appears to have increased over the post-crisis period. And Figure 14 shows the spread of a Bank of England measure of global investment-grade corporate bonds (non-finanical, non-utility corporates) to the relevant risk-free rate, weighted by market value. For these bonds the change in spreads from the last half of 2007, to the last half of 2018 was marginal, and worth no more than around 10bps. This in part reflects the fact that the spread moved significantly in the last half of 2007, entering $\mathrm{H} 1$ at around 80bps and ending 2007 at closer to $150 \mathrm{bps}$.

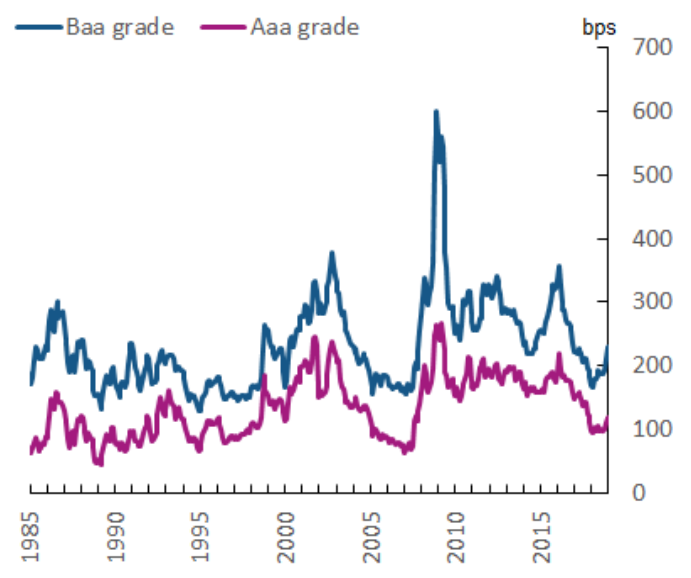

Figure 13: Data from the Federal Reserve Bank of St Louis (2020) - series AAA10YM and $B A A 10 Y M{ }^{a}$

\footnotetext{
$a_{\text {Moody's Seasoned Aaa and Baa Corporate Bond Yield Relative }}$ to Yield on 10-Year Treasury, at constant maturity.
}

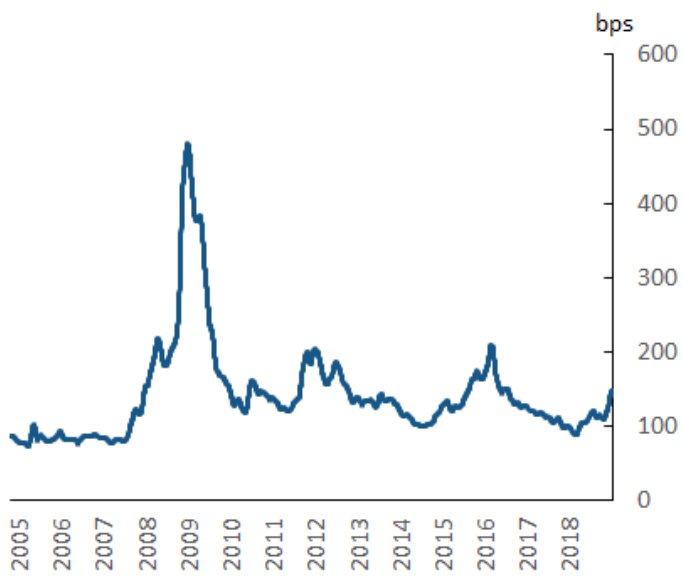

Figure 14: Spread of global aggregate market non-financial, non-utility corporate bonds to maturity-matched government spot rates.$^{a}$

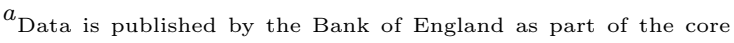
indicator series for the countercyclical capital buffer. Spread considers investment-grade corporate debt.
} 
Table 3: The effect of the decline in the risk-free rate on house prices - adjusting for the risk premium evidence

\begin{tabular}{|l|l|l|l|l|l|}
\hline \multirow{3}{*}{$\begin{array}{l}\text { Period } \\
\text { co }\end{array}$} & $\begin{array}{l}\text { Growth in house prices } \\
\text { due to changes in gilt } \\
\text { yields and risk premia } \\
\text { (per cent) }\end{array}$ & $\begin{array}{l}\text { Growth in house } \\
\text { prices due to } \\
\text { tax changes } \\
\text { (per cent) }\end{array}$ & $\begin{array}{l}\text { Growth in house prices } \\
\text { due to rising aggregate } \\
\text { real income } \\
(\text { per cent })\end{array}$ & $\begin{array}{l}\text { Combined: growth in house prices } \\
\text { due to falling gilt yields, risk } \\
\text { premia, tax changes, real incomes } \\
\text { (per cent) }\end{array}$ \\
\hline $1985-2018$ & $109 \%$ & $-16 \%$ & $83 \%$ & $176 \%$ & $124 \%$ \\
\hline $1985-2008$ & $64 \%$ & $-12 \%$ & $71 \%$ & $153 \%$ \\
\hline $2008-2018$ & $28 \%$ & $-1 \%$ & $6 \%$ & $33 \%$ & $-11 \%$ \\
\hline
\end{tabular}


Taken together, an increase in the risk premium on a wide range of assets that are alternatives to investing in residential property in the post-crisis period in the order of 200bps relative to where it was in 2007 seems plausible. It also seems that risk premia had been falling going into the crisis. So in Table 3, we maintain the average wedge across the whole period (in effect, continuing to set the wedge to 6.4 in both 1985 and 2018), but allowing it to fall to around 4.4 by the end of the pre-crisis period (2007) and then rising by 200bps between end-2007 and 2018 . Not surprisingly making this allowance for the change in the risk premia either side of the global financial crash makes a big difference - increasing the predicted rise of house prices before the crash and substantially reducing it after.

\section{Time series evidence and the calibrated model assumptions}

The calibrated model of the housing market used in this paper ascribes a major role to changes in real interest rates and to shifts in household incomes as primary drivers of house prices. It assumes that these forces are largely exogenous to housing market conditions. In this section we consider whether the time series properties of the UK data are consistent with this. To assess the assumptions that lie behind the calibrated model - both in terms of its predictions about the short and long run effects of changes in the driving variables and their exogeneity - we estimate vector autoregressions of UK house prices, incomes and real interest rates. In doing so we allow for any long run relations to show up in error correction terms that make short run changes in house prices, household incomes and real gilt yields potentially all respond to deviations from any

long run (equilibrium) relations. The vector error correction model (VECM) is particularly useful in assessing the key assumption that changes in gilt yields are largely unanticipated, permanent and independent of housing market conditions.

We use the same quarterly data on UK house prices, incomes and the safe real rate (based on 10 year real gilt yields) from 1985 to 2018 as in the calibrated model. Table 4 shows that standard tests for the order of integration of the variables suggest that all are non-stationary in levels; Augmented Dickey Fuller (ADF) tests are consistent with variables being integrated of order 1 so that the first differences in the log of real house prices, of log aggregate real household incomes and of real interest rates are stationary.

In a densely populated economy like the UK with rising population and increasing per capita incomes it is not surprising that aggregate household disposable incomes and real house prices are 
Table 4: Augmented Dickey Fuller test results

\begin{tabular}{|l|l|l|l|}
\hline Variable & Test statistic & Lag order & $p$-value \\
\hline 10 year index-linked gilt yield & -2.633 & 5 & 0.313 \\
\hline Log real income & -1.585 & 5 & 0.749 \\
\hline Log real house prices & -1.880 & 5 & 0.627 \\
\hline$\Delta$ 10 year index-linked gilt yield & -5.541 & 5 & 0.010 \\
\hline$\Delta$ log real income & -4.844 & 5 & 0.010 \\
\hline$\Delta$ log real house prices & -3.485 & 5 & 0.046 \\
\hline
\end{tabular}

non-stationarity. That real interest rates seem to have a unit root is more surprising, though it is what is implied by the calibrated model we have developed and where changes in real yields on inflation indexed bonds are both assumed to be unanticipated and permanent.

A simple OLS regression of log real house prices on the level of incomes and of real interest rates yields one candidate for a long run relation of:

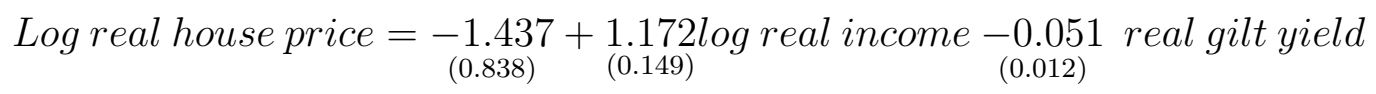

$R^{2}=0.755$; Dickey-Fuller statistic -2.20 ; standard error of coefficients in parentheses.

The residuals from this regression are not clearly stationary so there is a question as to whether this is a co-integrating relation between the $\mathrm{I}(1)$ variables, though Johansen techniques for identifying all possible cointegrating vectors between the variables consistently identified at least one (though no more than one) cointegrating vector. Embedding the residuals from this relation in a VAR also generates coefficient estimates that imply house prices respond in a stabilising way to deviations from a long run relation given by the OLS levels regression. Table 5 shows the VAR estimates from the differences of the variables applying this Engle-Granger two step procedure using the levels equation residuals as an error correction term; this error correction terms is positive (negative) when house prices are above (below) the long run relation. Single lags of first differences of logged variables seemed sufficient to model the dynamics of the three interrelated variables.

The coefficient on the lag error correction term is not significant either statistically or economically for changes in gilt yields and real incomes. But it is much more significant in the house price equation, suggesting that house prices do nearly all the adjustment to deviations in 
Table 5: VAR results with Engle-Granger 2-step residuals

Dependent variable:

$\Delta$ Log real house prices $\Delta 10$ year index-linked gilt $\Delta$ Log real income

\begin{tabular}{|c|c|c|c|}
\hline \multirow{2}{*}{$\Delta$ Log real house prices $_{-1}$} & $0.488^{* * *}$ & -1.567 & 0.030 \\
\hline & $(0.081)$ & $(0.953)$ & $(0.047)$ \\
\hline \multirow{2}{*}{$\Delta 10$ year index linked gilt -1} & 0.0003 & 0.011 & 0.001 \\
\hline & $(0.007)$ & $(0.087)$ & $(0.004)$ \\
\hline \multirow{2}{*}{$\Delta$ Log real income $_{-1}$} & -0.137 & 1.522 & 0.107 \\
\hline & $(0.159)$ & $(1.870)$ & $(0.092)$ \\
\hline \multirow{2}{*}{ Error correction term -1} & $-0.024^{*}$ & -0.015 & -0.003 \\
\hline & $(0.013)$ & $(0.156)$ & $(0.008)$ \\
\hline Observations & 134 & 134 & 134 \\
\hline$R^{2}$ & 0.238 & 0.021 & 0.021 \\
\hline Adjusted $R^{2}$ & 0.214 & -0.009 & -0.009 \\
\hline
\end{tabular}

the relation between the three variables from their equilibrium values. Lag changes in real house prices also appear to have no statistically significant relation to subsequent changes in incomes or interest rates. All this is consistent with the idea that incomes and real interest rates affect housing markets strongly but are largely independent of feedbacks from the housing market.

Figures 15 and 16 show the impulse responses for this VECM to shocks to real interest rates and to real household incomes. The shocks are of $1 \mathrm{pp}$ to the level of gilt yields and of $1 \%$ to incomes. These impulse responses are calculated assuming zero contemporaneous correlations between shocks; we found that allowing for correlations and trying different causal orderings made little difference to long run responses.

The second panel of Figure 15 shows that a shock to the level of the real longer-term interest rate is permanent. The impact on log house prices of a $+1 \%$ shock to real interest rates (top panel) is ultimately to reduce them by around 0.06. That impact on real house prices is lower than the calibrated model predicts and takes longer to come through. The fall of almost 6 percentage points in real gilt yields from the early 1980s up to 2019 would have generated around $45 \%$ higher real house prices according to the VECM but close to $100 \%$ with the calibrated model. This difference 
is likely to be due to the specification of the 3 equation VAR using levels of the real interest rate rather than the log of the user cost (which the calibrated, theory-based model implies). That choice was made because the main purpose of looking at the time series evidence is to gauge whether real interest rates themselves follow a near random walk and move independently of conditions in the housing market - which is indeed what the evidence reveals.

Figure 16 shows the long-run impact of a shock to incomes is also permanent and builds up gradually so that a $+1 \%$ shock eventually raises incomes by around $1.3 \%$ and has a slightly more than 1 to 1 impact on log real house prices which ultimately rise by around of $1.5 \%$.
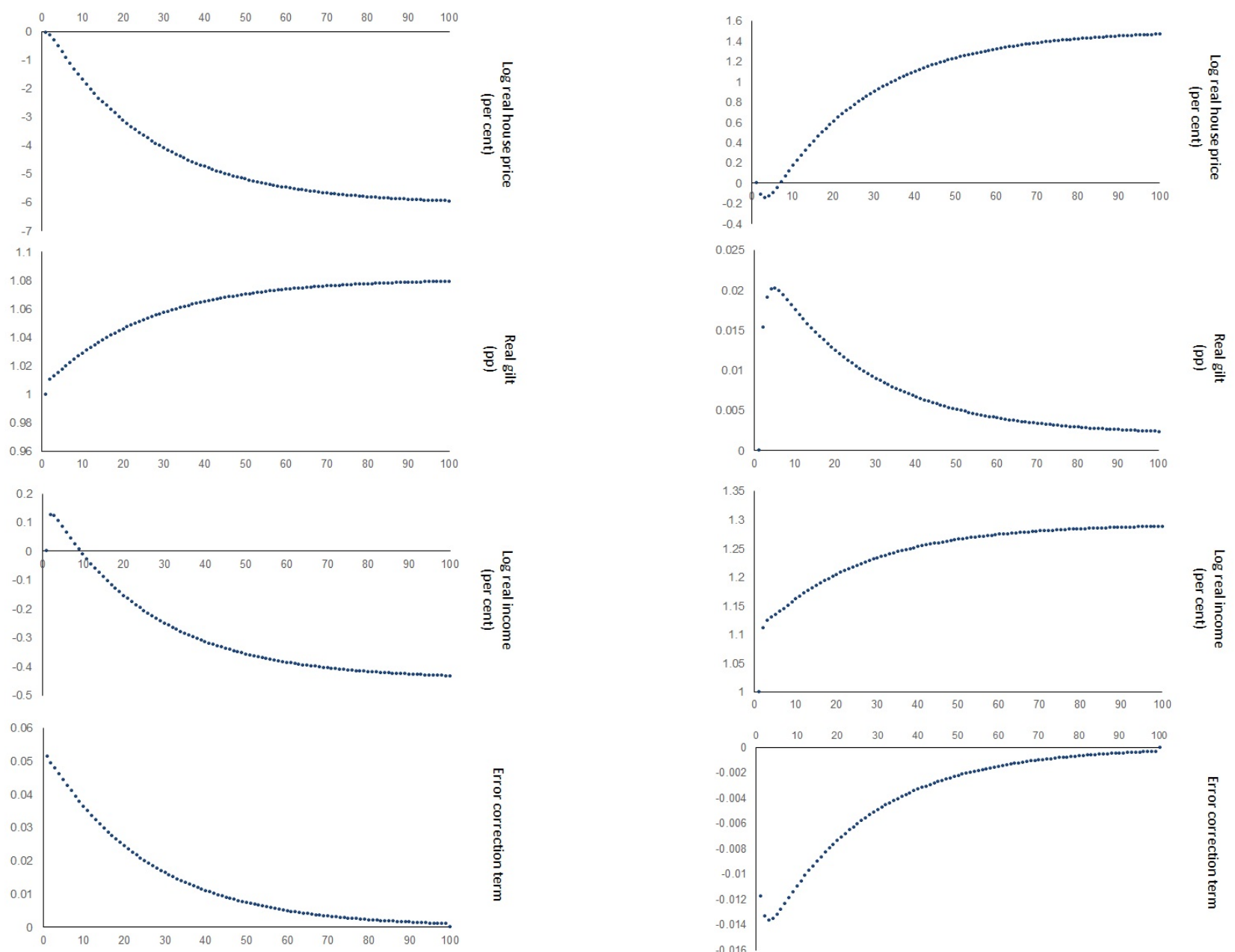

Figure 15: Impulse response to a 1 percentage point shock to real gilt yields.

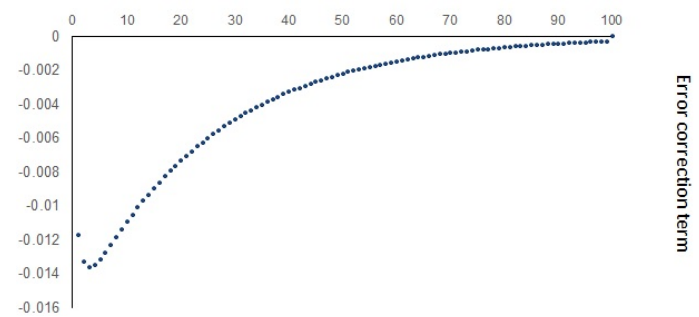

Figure 16: Impulse response to a 1 percent shock to real incomes

Impulse responses from applying the Johansen procedure are little different from the application of the Engle-Granger two step procedure; they show that shocks to interest rates and to incomes are highly persistent and have substantial effects on house prices; disequilibrium in house values 
generate subsequent adjustments in house prices but there seem to be small feedbacks on incomes and insignificant effects on gilt yields.

\section{Regional differences}

As was noted at the outset, this paper focuses on the national housing picture. We have not offered an account of regional differences in the trajectory of house prices, though these have been large. In particular, three major forces have shaped the pattern of house prices in the UK over the past several decades in a way that has generated significant differences across regions.

The first is de-industrialisation. Even though it occurred in the 1970s and 1980s, it has had a profound long-run affect on the regions affected. This is largely because the housing stock is slow to change in areas where jobs have disappeared (so house prices fall to clear the market), and also slow to rise in areas where new jobs have arrived(resulting in house price rises). This is a common phenomenon across developed countries - it can be seen in the very different path that house prices have taken since the 1970s in Detroit and San Francisco as much as in differences between Liverpool and London.

A second, related, factor which the aggregate model does not speak to is differences in the elasticity of supply of housing across regions. Such elasticities are clearly not uniform across the $\mathrm{UK}$, in part because restrictions are tighter in some areas than others. The Green Belt around London has restricted new building at the periphery of the capital city for many decades while restrictions around some of the former industrial towns of the UK away from the South East have been far less significant. A natural consequence of this is that, as overall demand for housing in the UK has increased with rising population and per capita incomes and with unanticipated declines in real interest rates, relative prices of housing have shifted. Houses in the south east have become far more expensive than those in much of the rest of the UK. Meen and Whitehead (2020) present details on how planning restrictions and supply elasticities differ across the UK and how relative house prices have changed over time to reflect this.

These two factors - de-industrialisation in several regions of the the UK, and regional differences in supply elasticites - are linked. Those regions which have lost jobs and people have a relatively under-utilised housing stock - they also have a willingness to see new houses built in areas close to urban centres where older industries have gone, leaving land available to develop. So declines in jobs and people have tended to come alongside high supply responsiveness to any increase in 
housing demand. This has naturally kept price rises down in the face of a substantial force driving demand up across all of the UK - namely the steady and large fall in the safe real interest rate.

The third major force is agglomeration. The tendency for high productivity jobs to concentrate in areas where such jobs already exist is a side effect of the local increasing returns to scale from spillovers in knowledge and the benefits of interaction. This has meant that some regions have seen wages and employment rise relatievly sharply, while other regions have fallen relatively further behind. Such agglomeration effects are more likely to exist in some service sectors (such as IT and financial services) and the rising importance of such sectors in the UK has exacerbated regional price differences in housing. This is, again, a common factor across countries.

One factor which our model implies is likely to have been important is that a decline in the safe real rate will be bigger in areas where people already expected capital gains to have been higher and the user cost was lower. The lower is the level of the user cost the greater is the impact of a further fall driven by lower real interest rates. Areas where the user cost was lower than the national average - because people believed prices would rise faster there - would find rental yields lower and would see bigger house price effects from changes in national real rates. This is a point emphasised by Himmelberg et al (2005) in their analysis of regional differences in US house price inflation.

\section{An international comparison}

The rise in house prices and the decline in real interest rates over the past 30 years has been a global phenomenon. So why have house prices in the UK risen much faster than in most other developed economies? There are three key reasons: (1) different growth rates of income; (2) different experiences of the risk-free rate; and (3) different elasticities that affect the housing market. (The first and third of these factors are very similar to those that account for the significant regional differences within the UK).

Looking first at incomes: since 1996 (the earliest time when comparable national data is available), growth rates in net household disposable income has varied considerably across the G7, ranging from around $0.2 \%$ annual growth in Italy all the way through to $2.6 \%$ growth in Canada. Indeed, those countries with the lowest annual rate of income growth (Italy, Japan, Germany), are also those whose real house price change was lowest 18

\footnotetext{
${ }^{18}$ Data is taken from the OECD series 'Household disposable income' which shows the net annual growth rate.
} 
Real yields on government bonds have also moved in different ways across countries. Using the data shared with us by Rachel and Summers (2019), we can make ready comparison between the UK experience and those of the other G7 countries.

- US 10 year inflation-linked bonds become available in 1997. Between 1997 and 2018, US bond yields fall by just under 2.5pp - whilst the corresponding figure for the UK is nearer $5.5 \mathrm{pp}$.

- For Canada, where inflation linked government bond yields are available from early 2000, the decline in yields was around 3.3pp whilst the UK's experience for the same period was nearer 4pp.

- The decline in yields on inflation proof French government debt was around 2.5pp from early 2003, the UK's was closer to 3.7pp.

- In Japan the government bond yield fell by less than 1.5pp from early 2004, whilst the UK experience was in the order of $4 \mathrm{pp}$.

- Germany's 10 year government bond data becomes available in mid-2009, and declines by $2.8 \mathrm{pp}$ between then and the end of 2018, comparing to around 3.2pp for the UK.

Finally, differences in the relevant elasticities play a key role in determining the extent to which changes in the user cost pass through to house prices. The UK has a particularly small price elasticity of supply compared to most other nations - OECD (2011) shows that the elasticity of the flow of supply in Canada and Japan is twice that of the UK, whilst the US is even greater still. Some evidence for the US suggests that the income elasticity of demand might be much lower than for the UK (see, for example, Albouy, Ehrlich and Yiu (2016) who estimate an elasticity of $0.7)$.

Taken together, we can see that even amongst the G7, there is significant variation in the key drivers of house prices that our model places front and centre.

To illustrate the difference this can make, consider a case where relative to the assumptions made for the UK we:

We set 1995 to an indexed level of 100, and then apply the growth rates in this series to the index until 2018. 
- double the price elasticity of supply (from 0.08 to 0.16 ) and reduce the income elasticity of demand from 1.3 to 0.7 , consistent with the (limited) evidence on the differences in elasticities between the UK and the other G7 economies; and

- set the path of reductions in real interest rates to be only two thirds of that seen in the UK.

We leave the UK income path and tax changes unchanged. With these changes the rise in real house prices over the period 1985-2018 is predicted to be $80 \%$ (of which around $35 \%$ would be due to income growth, $56 \%$ due to falls in real interest rates, with a small offsetting effect from taxes) - less than half of the $176 \%$ estimated using UK data only, in Table 2.

The significant heterogeneity in house price paths both across countries and across regions within the UK is not inconsistent with the notion that risk-adjusted rates of return should be equalised across assets that could be part of investors portfolios. Our estimates suggest that a major factor behind shifts in demand has been dramatic falls in real interest rates that have been unanticipated. After such falls, and as demand has risen, the balance between quantity responses and price responses is inevitably different when elasticities of housing supply vary. But we would expect price changes (and indeed price levels) to look very similar if homes in different places were close substitutes as places to live - and it is very clear that they are not. A house in central London and a house in Belfast (let alone one in rural South West France or in the north of Poland) are not close substitutes even if their structure, numbers of bathrooms and bedrooms is the same. Proximity to family, friends and to suitable jobs are self evidently of enormous significance and mean that great price differences persist; they are not a transient disequilibrium. Indeed, they would tend to rise if there are agglomeration forces at work.

\section{Why did real rates fall?}

We argue that the decline in real interest rates on safe assets has been a major factor behind the huge increase in house prices in the UK. We have also shown that this decline in real rates - which to a large extent is a common feature across major developed economeis - has had a larger impact on house prices in the UK than in most other countries because the sensitivity of supply to house prices is rather weaker in the UK than in most other countries.

But in placing the fall in real interest rates at the heart of the house price story we should further address two questions. First: was that decline itself largely independent of other forces 
affecting UK house prices? Second - and the more fundamental question - what is it that has driven real interest rates down so much?

We believe there is strong evidence that the decline in medium-term real interest rates is largely the result of the net effect of a variety of forces on the balance between the overall supply of savings and the overall demand for savings for investment within developed economies. These forces seem to have been at work over a period of decades that long pre-dates the financial crisis of 2007-08 and the large scale bond purchases by several central banks that came in its wake. Over a sustained period going back to the 1980s there have been changes that have shifted the savings schedule to the right and the investment schedule to the left resulting in a fall in price (that is, the real interest rate) to clear the market for funds within what is, essentially, a closed capital market at the level of the aggregate economies of the rich large countries.

Summers and Rachel (2019) articulate the argument clearly and present several different types of evidence to support it: we find their evidence compelling. Summers and Rachel attribute the main reason for the decline in real rates down to private sector developments (partly demographic) which have substantially raised desired saving relative to private desired investment and which have been less than fully offset by public sector policies (on pensions, other social security benefits and on overall fiscal deficits). They summarise their findings thus:

"....much of the available evidence points to a common underlying decline in real interest rates across different financial assets. This suggests that saving and investment propensities and how they changed over time is the dominant underlying driver of such trend.... The decline in the neutral real rate of this magnitude is a symptom of deep, fundamental changes that have taken place in the developed economies over the last half-century. A useful way to think about these trends is through the lens of desired saving and investment, with the desire to save running ahead of the desire to invest..... the neutral real rate for the industrial world has trended downward for the last generation and this is best understood in terms of changes in private sector saving and investment propensities. In the face of neutral real rate estimates, past trends in indexed bond yields, and measures of real swap yields, this conclusion seems inescapable."

Having studied the empirical evidence on shifts in trend GDP and real interest rates they reject the idea that it is changes in expected income growth that caused much of the decline in real rates. This is significant because if shifts in expected real incomes caused the fall in rates - and such shifts also had an independent impact on house prices - this would contaminate our 
estimates. (In fact it would suggest the effect of falls in real rates was probably rather bigger than we estimate.) More generally, the drivers that Rachel and Summers identify as powerful shifts in savings driven by demographic changes, fiscal policy changes and shifts in technology that reduce the need for capital investment to boost output capacity - all operate at the level of the aggregate OECD countries rather than for individual countries. Such forces would seem to be largely exogenous to conditions specific to the UK housing market.

We believe this makes our assessment of the independent impact of changes in real rates on UK housing informative. But the scale of the fall in real interest rates estimated by Summers and Rachel for the G7 since the 1980s (of around 3.5\%) is smaller than our estimate of the decline in UK index linked gilts (of above 5\%). One significant, and UK specific, factor that helps account for the larger decline in UK safe real rates is the substantial shift over this period in the demand for long-term inflation proof assets by UK pension schemes as they alter portfolios away from equities towards bonds that better hedge Defined Benefit pensions. This significant factor has been largely driven by regulatory and accounting changes, so is unlikely to be caused by shifts in the supply and demand for UK housing.

\section{Policy implications}

There are a number of consequences of our findings for policymakers.

For the government, housing affordability (or lack thereof) raises significant consequences for labour mobility. Significant rises in real house prices also have substantial distributional consequences. Most UK homeowners (typically, older) will have experienced decades of gain in the price of their asset, and enter old age relatively wealthy, regardless of income. Younger cohorts, who have been on the wrong side of the house price increase, have struggled to afford the minimum deposit required to arrange mortgage financing - particularly in the post-crisis period - as house price increases have outpaced their income. Family wealth becomes more important: young people with access to 'The Bank of Mum and Dad' are more likely to be able to access home-ownership; those whose family do not have income to share but have benefitted from decades of house price growth, will be helped into home-ownership via inherited wealth; that leaves a group for whom family income and wealth cannot support aspirations for home-ownership. This last category will struggle to access home-ownership unless they are amongst the highest earners. Concern about 
the affordability of housing for young people is one factor behind the announcement by the UK Government in August 2020 of proposals for a more permissive regime for housing development, so as to boost new supply and slow the rise in house prices.

The distributional consequences of rising house prices are, however, not straightforward. Housing is more equally held than most forms of wealth - it is much more evenly distributed than equities. Rising house values have an ambiguous impact on overall wealth inequality. Grossman et al (2019) show that the distributional consequences of rising housing costs are complicated and sometimes counter-intuitive. In their model the wealth distribution is stationary even in a growing economy with rising housing costs. But transitional dynamics from a shift in policy do cause changes in the steady state distribution of wealth. In their model a relaxation of planning restrictions, for example, re-distributes wealth to the least well off. Changes in real interest rates have more complicated effects because they alter the return on non-housing assets.

For financial stability policymakers, there is good news in our findings. Whilst we do not reject the temporary role of exuberance and pessimism in determining house prices, our findings suggest that residential property prices in the UK have not exceeded their fundamental values - a sharp, costly adjustment from the bursting of a bubble is not on the horizon 19 But that means that, absent policy interventions, high levels of house prices relative to incomes are probably here to stay, at least in the medium-term. The household sector may therefore be expected to remain relatively highly leveraged. Consistent with the literature on household spending adjustments in a downturn, this implies that future downturns may be exacerbated by households cutting consumption in order to service mortgage debt (see for example, Bunn and Rostom (2018), and Mian and Sufi (2010)). A careful consideration of debt-servicing ratios and household resilience to income and/or interest rate shocks may guard against this.

It also further strengthens the case for prudential measures on mortgages. In a world of persistently higher house prices relative to incomes, monthly debt-servicing costs for many new buyers will be higher (and so the ratio of those costs to their income, the 'debt-servicing ratio' higher). This is offset by unusually low nominal interest rates, though how long near-zero central bank policy rates will last is far from clear. Many households have responded to the need to

\footnotetext{
${ }^{19}$ The Covid-19 pandemic is likely to have consequences for the UK housing market, however at this stage it is unclear what those will be in the long term. The immediate response has been a slight acceleration in national house price increases. This may be a transitory impact of a time-limited cut in stamp duty - a transactions cost falling on home buyers.
} 
take on much higher mortgages by extending the term of the mortgage: the share of new UK mortgages taken out with terms of at least 30 years tripled between 2005 and 2017. Higher mortgage debt exacerbates the stress caused by income shocks (including unemployment) to a household, raising default risks. Taking out mortgages for longer terms also poses a risk to the resilience of the household sector - for whom working longer into old-age may become a necessity, which may neither be desirable or, for some (such as those with manual jobs or who suffer ill health), possible. Setting minimum underwriting standards, by assessing a borrower's ability to afford a mortgage product were they to face a shock to their household incomes, is therefore important. Such standards are now mandatory for lenders in the UK. The Bank of England's Financial Policy Committee has instituted an affordability recommendation, which is implemented by the supervisors of UK lenders. This is motivated by concern for the resilience of the UK banking sector, consistent with the remit of that Committee. But there is also a consumer welfare case for reducing the risk of households taken on more debt than is in their interests. To some this sounds excessively paternalistic. Yet the evidence that UK households underestimate such risks is strong. 20

The effect of changes in the interest rate on house prices are more significant at lower interest rates: for as long as we are in a low interest rate environment, the potential for house prices adjusting rather dramatically in response to changes in the interest rate remains. This may have yet further consequences for the resilience of bank balance sheets, particularly those banks and/or building societies significantly exposed to the UK mortgage market.

As set out earlier in the paper, the trajectory for the real risk-free rate has for decades been gently downwards - though one would expect that this cannot continue indefinitely. The decadeslong decline is likely based on economic fundamentals (e.g. shifts in global saving, falls in the need for such large-scale investment as was required in earlier periods of industrialisation, slow-moving demographic changes). These may be slow to be reversed; though there is no guarantee of that. If it is reversed sharply the message of this paper is that we can expect large falls in house prices. Ensuring that the UK banking system is resilient to this potential risk is a key part of macroprudential regulation. The Bank of England's stress testing of the largest UK lenders assesses their resilience to scenarios that include substantial falls in house prices - in the 2019 test, for example, UK residential house prices were assumed to fall by more than $30 \%$ - not far off

\footnotetext{
${ }^{20}$ See, for example, Miles (2004) and Miles (2003).
} 
twice the fall in the 2007-08 global financial crisis. The results of this paper suggest that applying such tests is sensible.

Higher mortgage debt also gives monetary policy more of a bite, particularly in a country like the UK where variable interest rates on mortgages are the norm and, where rates are fixed, they are fixed in the main for only two or three years.

\section{Some policy measures}

We note above the consequences of this higher level of house prices. Now we consider possible interventions to alleviate some of these pressures.

The most common proposal for mitigating house price increases is to increase the supply responsiveness to price. In theory, this may have a significant effect over the long-run. If people are forward-looking and believe there is a permanent, significant and positive supply response from higher house prices, then this could dampen price changes well ahead of the actual rise in the stock of housing. But we find that even large changes in the elasticity of the flow of housing investment translate into modest changes in the elasticity of the stock of housing - and it is the stock that matters. Looking back to Equation 13, and doubling the price elasticity of supply (from 0.08 to 0.16$)$, we get:

$$
\Delta \ln \left(P_{t}^{H}\right)=0.9 \cdot g_{y}-0.8 \cdot \Delta \ln \left(R_{t}+\delta_{t}+P O_{t}-E\left[\rho_{t}\right]+R P_{t}\right)
$$

When the elasticity of supply was 0.08 , the model predicted house price growth of $176 \%$, as per Table 2. Having doubled the price elasticity of supply, the model predicts house price growth of $152 \%$. This implies that a very substantial rise in supply responsiveness could probably only unwind a small fraction of the huge rise in house prices - even with perfect credibility in such a response, and a substantial increase in housebuilding maintained over decades. How best policy can increase that elasticity remains a significant issue. Recent research by Miles and Sefton (2020) suggests that one of the best ways to do this is indirectly through transport improvements (so as to get around the difficulty in building more houses near urban centres already densely populated but where people need to be for work), but this will take a considerable time to achieve.

But the main finding of this paper is that the big factor behind real house price increases has not been a sluggish supply response that can easily be addressed; rather it is has been an enormous 
fall in the level of real interest rates. Why this has such a powerful impact stems from the effect it has on the user cost of housing. It could, of course, reverse if real rates rise - but that is something not easily influenced by policymakers in one country who control the short-term nominal rate and not the longer term real rate. Monetary policy can change short term real rates for a while when inflation (and inflation expectations) might be sluggish, but the scope of monetary policy to affect longer term real rates is much more limited. Causation more likely runs from underlying drivers of real rates (saving and investment schedules shifting) to the level of short-term nominal rates rather than the other way around. One reason why nominal rates are so low is that the likely level of the natural real rate is much lower than a few decades ago (which is reasonably proxied by the yield on a long-dated inflation-proof government bond) and inflation is broadly anchored to a similar level (UK evidence indicates that expected inflation stays close to the Bank of England's $2 \%$ target). And, even if monetary policy could be tilted towards higher rates so as to reduce house prices, it is doubtful that it should - this would create distortions elsewhere, in the cost of capital and the level of productive investment.

But the model for house prices which has as its heart the user cost of housing implies that other levers are just as powerful (percent for percent) as change in real rates - in particular housing taxes. Housing is arguably undertaxed in the UK: services of home ownership (the imputed income from housing) is not taxed and capital gains for owner-occupiers are tax free. A strong case can be for made for addressing the former: the Mirrless report (2015) sets out that case in detail; Muellbauer (2018) also makes this case. VAT is charged at $20 \%$ on most consumer goods in the UK while consumption of owner-occupied housing services is essentially tax-free. The rental yield on housing in UK in recent years has been around $5 \%$ and with house prices in many parts of the country at 5 or more times annual disposable income, consumption of housing at $25 \%$ of income is not unusual. To tax housing consumption in line with that of goods paying $20 \%$ VAT would require, at a rental yield of $5 \%$, a $1 \%$ annual tax on house value. This would offset a $1 \%$ decline in real rates. In an important sense such a tax change does not make home-ownership more or less affordable precisely because the change in tax is offset by the shift in price. But the tax shifts the timing of costs for a new home owner - it could bring a significant reduction in the price paid up front for a house in exchange for higher annual costs of living in the house. Many young buyers would find this welfare enhancing, and it would help address some of the concerns detailed at the outset of this section. An annual tax proportional to house value would also be much less 
regressive than the current tax system in UK - again this is helpful to new buyers who have lost out from the large rise in the relative cost of housing.

Inevitably such a tax change will create losers - those who had bought their first homes just before such a change take the capital loss (possibly generating negative equity) but face the higher taxes. A gradual transition to a new tax regime lessens such problems, but at the expense of delaying more appropriate taxation of housing.

\section{Concluding remarks}

In this paper we have presented evidence connecting the decline in the real yield on index-linked gilts, as a proxy for the risk-free rate, to rising house prices and falling rental yields over the long term. The conclusions are stark - since 1985, the observed decline in index-linked gilt yields and other changes in the cost of home ownership are associated with an increase in house prices of around 90\%; income rises account for about a further rise of $80 \%$ - between them these factors account for all of the observed rise in UK house prices.

This does not mean that other factors are unimportant for short-run fluctuations in prices; the equilibrium conditions explored here provide an explanation for the long-run trajectory in house prices. Over shorter horizons house prices will be driven by other factors - such as movements in mortgage availability, shifts in uncertainty and the ups and down of the business cycle. But over the longer term one can account for all of the rise in house prices relative to incomes as being due to persistent declines in real interest rates.

Today global yields on inflation-proof government bonds are at a historical low. In the UK, the 10 year index-linked gilt yield at the end of 2019 was $-2.4 \%$. Were the 35 year trend to reverse, and gilt yields to rise rather than fall, this research indicates that there would be a very substantial long-term consequence for real house prices. Our results suggest that a $1 \%$ change in real interest rates that was persistent could move real house prices by around $20 \%$ across many years.

This calculation illustrates the sensitivity of house prices to changes in interest rates. But it does not suggest that house prices are likely to move lower. That would only be reasonable if a reversal of the 35 year downwards trend in safe real interest rates seemed likely. But measures of real interest rates in the UK and other developed countries show little sign of mean revision (see Figures 5, 6 and 7). We also noted that forward rates consistently move in line with spot 
rates implying that the bond markets' best estimate of yields in the future has generally been the current rate. That is consistent with a random walk model of real yields and not with mean reversion. Nor do explanations of the current low level of real interest rates - be they based on secular stagnation hypothesis or a savings glut story - give much reason to anticipate a reversion to higher real rates.

There are factors beyond rising real interest rates that could bring house prices in the UK down. But the calculations described in this paper - which show the overwhelming importance of falling interest rates in driving up house values - suggest that the effects might be relatively small. Even a doubling in the supply elasticity in the UK would have had a relatively small impact on house price rises over the past 35 years. Only an implausibly large rise in house building could change the stock of housing enough to unwind more than a small part of the rise in values over the past few decades.

What has happened in the UK - and to a lesser extent in other countries - is ultimately not such a mystery. The value of a long lived real asset that generates a flow of services over many decades and whose aggregate supply is slow moving is likely to be driven up dramatically if the real discount rate used to value those future benefits declines dramatically. The bad news is that this rise in price does not reflect a rise in the intrinsic benefits generated by the housing stock. It has significant consequences for policymakers: for those concerned with financial stability, it may be reassuring that this evidence does not point to a bubble, but it indicates that high levels of mortgage debt to incomes may be here to stay (at least in the medium-term). House price rises also create large inter-generational shifts in wealth. Ultimately most of the rise in value will flow down to future generations in the form of inheritances. But it will do so unevenly - so while the inter-generational redistribution will (to a significant extent) ultimately be self-correcting, the intra-generational shift in the distribution of wealth may not be. 


\section{Appendix: Household optimisation, the user cost and rents}

We assume that agents (indexed by $i$ ) derive utility from the consumption of goods, denoted $C$, and of housing services. Housing services are assumed to be proportional to the (quality-adjusted) size of the house $\left(H_{i}\right)$ - which is the number of units of housing the household enjoys. We can express utility as a function of consumption of goods and of the size of the house in which the agent lives (either rented or owned). Preferences over these goods at a given time $t$ is described by a utility function which shows the flow of utility for agent $i$ at time $t$ (denoted $Q_{i t}$ )

$$
Q_{i t}=U\left[C_{i t}, H_{i t}\right]
$$

Lifetime utility $\left(W_{i}\right)$ is the discounted sum of per period utility

$$
W_{i}=\sum_{t=0}^{T} Q_{i t} /(1+\eta)^{t}
$$

$\mathrm{T}$ is the planning horizon; $\eta$ is the discount factor (rate of time preference).

Assume initially that the household can borrow enough with a mortgage (of size $M$ ), in conjunction with accumulated net financial wealth $S$, to buy a house which generates housing services. Assume also that the real return on financial assets and the real interest rate on mortgage debt are both equal to $r_{t}$. This rate $r_{t}$ is not the safe rate (which we denote $R_{t}$ ) because the average asset that households hold in their portfolio of non-housing wealth $\left(S_{i t}\right)$, as well as mortgage debt, are both assumed to be less secure than is the return on a truly riskless real asset, such as an inflation indexed government bond. For simplicity of notation, assume that the risk premium on both $S$ and $M$ is $R P_{t}$ so that $r_{t}=R_{t}+R P_{t}$.

The consumption good is the numeraire. The period to period budget constraint is:

$$
C_{i t}=Y_{i t}+\left(1+r_{t}\right) S_{i t-1}-S_{i t}-\left(1+r_{t}\right) M_{i t-1}+M_{i t}-P_{t}\left(H_{i t}-(1-\delta) H_{i t-1}\right)-P_{t} H_{i t}\left(P O_{t}\right)
$$

subject to the constraints:

$$
\begin{aligned}
& S_{i t} \succeq 0 \\
& M_{i t} \succeq 0
\end{aligned}
$$


$S_{i T}+P_{T} H_{i T}-M_{i T} \succeq 0$

where:

$Y_{i t}$ is labour income;

$P_{t}$ is the price of a unit of housing at time t in terms of consumer goods;

$P O_{t}$ is the tax rate on housing for owners of property, and $P_{t} H_{i t}\left(P O_{t}\right)$ is total tax paid; and

$\delta$ is the cost of home maintenance (to offset depreciation) plus other home ownership costs that are related to the size of the property, such as insurance.

The first order conditions for optimal consumption of goods and of housing services are:

$$
\begin{gathered}
d U_{i} / d C_{i t}=\left[\left(1+r_{t}\right) /(1+\eta)\right] d U_{i} / d C_{i t+1} \\
d U_{i} / d H_{i t}=d U_{i} / d C_{i t}\left[P_{t}\left\{r_{t}+\delta+P O_{t}-\rho_{t}\right\}\right]
\end{gathered}
$$

where $\rho_{t}$ is the rate of change of house prices (i.e. the rate of real capital gains on housing, which we assume is untaxed)

The optimising condition (Equation 19) is that the rate of substitution between housing services and consumer goods, $\left(d U_{i} / d H_{i t}\right) /\left(d U_{i} / d C_{i t}\right)$, should equal the rate of transformation in cost terms, $P_{t}\left\{r_{t}+\delta+P O_{t}-\rho_{t}\right\}$, where the latter is the user cost of housing. The user cost is the real cost of housing services. If we substitute in the relation between the safe rate of interest and the return on both mortgages and non-housing wealth (that is $r_{t}=R_{t}+R P_{t}$ ) we can write the user cost $\left(U C H_{t}\right)$ as:

$$
U C H_{t}=P_{t}\left\{R_{t}+\delta+P O_{t}-\rho_{t}+R P_{t}\right\}
$$

This is the form of the user cost formula used in our analysis, and as shown in Equation 2 in the main text.

If there are some households that are indifferent between renting and owning then rent paid must equal the user cost of housing, a condition we assume holds. 


\section{Bibliography}

Albouy, D., Ehrlich G., and Liu, Y., (2016). "Housing demand, cost-of-living inequality, and the affordability crisis". NBER Working Paper Series: 01 July 2019. Available from: https: //www.nber.org/papers/w22816.pdf

Andrle, M., and Plašil, M., (2019). "Assessing House Prices with Prudential and Valuation Measures", Working Paper 19/59, International Monetary Fund, Washington DC.

Bank of England (2018). Financial Stability Report, June 2018, Issue No. 43.

Barker, K., (2004). "Review of Housing Supply". Place of Publication: BBC. [01 February 2019] Available from: http://news.bbc.co.uk/nol/shared/bsp/hi/pdfs/17_03_04_barker_ review.pdf

Bunn,P., and Rostom, M., (2018). "Consumption response to aggregate demand shocks and the role of leverage", Centre for Macroeconomics Discussion Paper 1820.

Case, K., Quigley, J. and Shiller, R., (2005). "Comparing Wealth Effects: The Stock Market versus the Housing Market". Advances in Macroeconomics 5(1)

Duca, J.V., Muellbauer, J., and Murphy, A., (2016). "How Mortgage Finance Reform Could Affect Housing," American Economic Review, American Economic Association, vol. 106(5), pages 620-624, May.

Ermisch, J.F., Findlay, J., Gibb, K., (1996). "The Price Elasticity of Housing Demand in Britain: Issues of Sample Selection". Journal of Housing Economics, 5(1), pp64-86

Board of Governors of the Federal Reserve System (2019). Financial Stability Report, November 2019.

Fraumeni, B., (1997). "The measurement of depreciation in the US national income product accounts". Survey of Current Business 77, 7.23.

Garriga, C., Manuelli, R., and Peralta-Alva, A., (2019). "A Macroeconomic Model of Price Swings in the Housing Market". American Economic Review, 109 (6): 2036-72. 
Geng, N., (2018). "Fundamental Drivers of House Prices in Advanced Economies," Working Paper 18/164, International Monetary Fund, Washington DC.

Glaeser, E., Gottlieb, J. B., and Gyourko, J., (2012). "Can Cheap Credit Explain the Housing Boom?" in Housing and the Financial Crisis, University of Chicago Press, 301-359.

Glaeser, E., Gyourko, J., and Saks, R., (2005). "Why Have Housing Prices Gone Up?", American Economic Review (Papers and Proceedings) vol 95, 2, pp 329-333.

Green, R., Malpezzi, S., Mayo, S., Harding, J., Rosenthal, S., and Sirmans, C., (2007). "Depreciation of housing capital, maintenance, and house price inflation: Estimates from a repeat sales model". Journal of Urban Economics 61(2), pp193-217.

Grossman, V., Larin, B., Löfflad, H. T., and Steger, T., (2019). "Distributional effects of surging housing costs under Schwabe's Law".CESIFO Discussion Paper 7684, May.

Harding, J., Rosenthal, S., and Sirmans, C., (2007). "Depreciation of housing capital, maintenance, and house price inflation: Estimates from a repeat sales model", Journal of Urban Economics 61(2), pp193-217.

Himmelberg, C., Mayer, C., and Sinai, T., (2005). "Assessing High House Prices: Bubbles, Fundamentals and Mis-perception “, Journal of Economic Perspectives, vol 19, pp 67-92.

Jordà, Ò., Knoll, K., Kuvshinov, D., Schularick. M., and Taylor, A. M., (2019). "The rate of return on everything, 1870-2015." The Quarterly Journal of Economics 134(3), $1225-1298$

Joyce, R., Mitchell, M., and Norris Keiller, A., (2017). "The cost of housing for lowincome renters. The Institute for Fiscal Studies: 01 July 2019. Available at: https://www.ifs. org.uk/uploads/publications/comms/R132.pdf

King, M., and Low, D., (2014). "Measuring the "World" Real Interest Rate". [28 March 2019] Available at: https://www.nber.org/papers/w19887.pdf

Kneuzel, R., and Bjornbak, B., (2008). "The UK Housing Market: Anatomy of a house price boom". [29 March 2019]. Available at: http://ec.europa.eu/economy_finance/ publications/pages/publication13282_en.pdf 
Knoll, K., Schularick, M., and Steger, T., (2017). "No Price Like Home: Global House Prices, 1870-2012" American Economic Review 2017, 107(2): 331-353

Kuvshinov, D., and Zimmerman, K., (2020). "The Big Bang: Stock Market Capitalization in the Long Run", CEPR Discussion Paper 14468

LBC Warranty (2019). "What is the average house size in the UK?" [1 June 2019]. Available at: https://www.labcwarranty.co.uk/blog/are-britain-s-houses-getting-smaller-new-data/

Malpezzi, S., and Wachter, S.M., (2012). "Housing Demand". International Encyclopedia of Housing and Home, pp404-407.

Meen, G., (2005). "On the Economics of the Barker Review of Housing Supply". [01 February 2019] Available at: https://doi.org/10.1080/02673030500291082

Meen, G., and Andrew, M., (1998). "Modelling Regional House Prices: A Review of the Literature, prepared for the Department of the Environment, Transport and the Regions". ISBN: 0704913054

Meen, G., and Whitehead, C., (2020). "Understanding Affordability: The Economics of Housing". Bristol University Press.

Mian, A., and Sufi, A., (2010). "Household leverage and the recession of 2007 to 2009", IMF Economic Review 58, pp74-117.

Miles, D., (1994). "Housing Financial Markets and the Wider Economy". John Wiley.

Miles, D., (2003). "“The UK Mortgage Market: Information, Incentives and Pricing". HM Treasury.

Miles, D., (2004). "The UK Mortgage Market: Final Report and Recommendations". HM Treasury.

Miles, D., and Sefton, J., (2020). "House Prices and Growth with Fixed Land Supply", forthcoming The Economic Journal.

Ministry of Housing, Communities and Local Government, (2018). "House building; new build dwellings, England: December Quarter 2017". [02 April 2019] Available at: https:// 
assets.publishing.service.gov.uk/government/uploads/system/uploads/attachment_data/ file/692680/House_Building_Release_Dec_Qtr_2017.pdf

Morgan, M., and Cruickshank, H., (2014). "Quantifying the extent of space shortages: English dwellings". Building Research and Information, 42(6), pp710-724.

Muellbauer,J., and Murphy, A., (1997). "Booms and Bust in the UK Housing Market". The Economic Journal, 107(445), pp1701-1727.

Muellbauer, J., (2018). "Housing, Debt and the Economy: a Tale of Two Countries," Economics Series Working Papers 855, University of Oxford, Department of Economics.

National Audit Office, (2017). "Housing in England: overview" . [11 March 2019] Available at: https://www .nao.org.uk/wp-content/uploads/2017/01/Housing-in-England-overview. pdf

OECD (2011). "The Price Responsiveness of Housing Supply in OECD Countries". [28 March 2019] Available at: https://doi.org/10.1787/5kgk9qhrnn33-en

Peachey, K., (2019). "Typical council tax in England will rise by $4.7 \%$ in April". British Broadcasting Corporation [online]. 27 March 2019. Available at: https://www.bbc.co.uk/news/ business-47718718

Poterba, J. (1984). "Tax Subsidies to Owner Occupied Housing: An Asset-Market Approach". The Quarterly Journal of Economics, 99(4), pp729-752.

Rognlie, M., (2016). "Deciphering the fall and rise in the net capital share: Accumulation or Scarcity?". Brookings papers on economic activity, 2015(1), pp1-69.

Royal Institute of British Architects (2015). "Space standards for homes". [1 June 2019] Available at: https://www .architecture.com/-/media/gathercontent/space-standards-for-homes/ additional-documents/homewisereport2015pdf .pdf

Sa, F., (2016). "The Effect of Foreign Investors on Local Housing Markets: Evidence from the UK". Accessed 12 March 2019, available at: https://papers.ssrn.com/sol3/papers.cfm? abstract_id=2877263 
Savills, (2019). "Value of UK housing stock hits record high". [20 May 2019] Available at: https://www.savills.co.uk/blog/article/274512/residential-property/value-of-uk-housing-stc aspx

Seely, A., and Keep, M., (2018). "Stamp duty land tax on residential property". House of Commons Library Briefing Paper no. 7050. London: House of Commons Library. Available at: https://researchbriefings.files.parliament.uk/documents/SN07050/SN07050.pdf

Skaburskis, A., (1999). "The effect of development charges on urban form: an econometric analysis". Canada Mortgage and Housing Corporation. [1 July 2019] Available here: http:// publications.gc.ca/collections/collection_2017/schl-cmhc/nh18-1-4/NH15-325-1999-eng. $\mathrm{pdf}$

Summers, L., and Rachel, L., (2019). "On Falling Neutral Real Rates, Fiscal Policy, and the Risk of Secular Stagnation". [28 March 2019] Available at: https://www.brookings.edu/ wp-content/uploads/2019/03/On-Falling-Neutral-Real-Rates-Fiscal-Policy-and-the-Risk-of-Se pdf

Swank. J, Kakes, J., Tieman, A., (2002). "The Housing Ladder, Taxation, and Borrowing constraints". [30 March 2019] Available at: https://econpapers.repec.org/paper/ dnbwormem/688.htm

Van Nieuwerburgh, S., and Weill, P., (2010). "Why has house price dispersion gone up?". The Review of Economic Studies, 77(4), pp1567-1606.

Hilber, C., and Vermeulen, W., (2016). "The Impact of Supply Constraints on House Prices in England". The Economic Journal, 126(591) pp358-405.

Williams, K., (2009). "Space per person in the UK: A Review of densities, trends, experiences and optimum levels". [20 January 2019] Available at: https://doi.org/10.1016/j. landusepol.2009.08.024 